\title{
EVERY SEAFARER HAS A PRIMARY DUTY THAT MAY PROVIDE THE BASIS OF A DEFENSE IN A PERSONAL INJURY ACTION
}

\author{
J. Patrick Geraghty*
}

\section{INTRODUCTION}

A seafarer injured while in the service of a merchant ocean vessel is accorded three causes of action against his or her employer: 1) Jones Act negligence, 2) the warranty of seaworthiness, and 3) maintenance and cure. The latter two causes of action arise under general maritime law, the first is statutory. ${ }^{1}$ This article deals with a defense to a seafarer's claims for Jones Act negligence and unseaworthiness. ${ }^{2}$ This defense, commonly known as the "Primary Duty Rule," has been restated in numerous variations since its inception. This article examines the history and evolution of the Rule and suggests a restatement of the Rule for continued application in the defense of seafarer personal injury cases.

\section{Primary Duty Rule}

The "Primary Duty Rule," sometimes called the "Walker Rule"3 or a combination of the two names, is often said to have its origin in Walker $v$.

* J. Patrick Geraghty is the Managing Partner at Geraghty Suarez, LLP in Hackensack, New Jersey and an adjunct professor of Admiralty Law at Rutgers School of Law, Newark, and Seton Hall University, School of Law. He is the sole author and researcher of this article, and dedicates the article to his father, John R. Geraghty, Esq., a giant in the field of Admiralty Law.

1. 46 U.S.C. $\$ 30104$ (a) (2006) provides:

Cause of Action.-A seaman injured in the course of employment or, if the seaman dies from the injury, the personal representative of the seaman may elect to bring a civil action at law, with the right of trial by jury, against the employer. Laws of the United States regulating recovery for personal injury to, or death of, a railway employee apply to an action under this section. 46 U.S.C. $\S 30104$ (2008).

(b) Venue.-An action under this section shall be brought in the judicial district in which the employer resides or the employer's principal office is located.

2. In this article, "owner," "employer" and "shipowner" are used as synonyms for the seafarer's employer, usually the vessel owner and/or operator; in short, the defendant to a seafarer's claim for negligence under the Jones Act or for unseaworthiness.

3. Walker v. Lykes Bros. S.S. Co., 193 F.2d 772 (2d Cir. 1952). 
Lykes Brothers S.S. Co. ${ }^{4}$ As this article will demonstrate, however, Judge Learned Hand's opinion in that case restated a rule that had been established in several previous Supreme Court cases. Subsequent to Walker, courts reinterpreted and refined the Primary Duty Rule. As a result, the Rule has become a source of disharmony among the circuits. ${ }^{5}$

\section{HisTORY}

In 1920, Congress passed the Jones Act, ${ }^{6}$ and, in a few lines of text, extended to seafarers all the rights of railroad workers under the Federal Employers Liability Act ("FELA"). ${ }^{7}$ Consequently, cases pertaining to rights and liabilities under FELA are precedential to cases brought under the Jones Act. ${ }^{8}$

The Jones Act permits a seafarer to sue his or her employer for ordinary negligence with a lowered causation standard. Essentially, this means if the owner's negligence was "a" cause of the seafarer's injury, as opposed to "the"

4. The court in Walker did not use the word "primary" in its decision. The court said,

if the plaintiff failed to repair the catches, although he was able to do so, his failure was not only "contributory negligence" in the first sense ["contributory negligence as the breach of a duty to the wrongdoer"] but also a breach of his duty to the defendant ["a duty which the injured person has consciously assumed as a term of his employment"] which barred his recovery absolutely. Id. at 774

5. According to the Federal Model Jury Charges, a defendant asserting the Primary Duty Rule must prove the following elements:

The defendant has introduced evidence that the injury to the plaintiff was caused solely because the plaintiff failed to perform a duty which he or she had consciously assumed as a term of employment. If you find that the defendant has proven by a preponderance of the evidence all three elements of this defense as I shall describe them, then you should render a verdict in favor of the defendant.

First, the defendant must prove that plaintiff's injury was caused by the plaintiff's failure to perform a duty which he or she had consciously assumed as a term of employment. This means that it was one of the plaintiff's principal duties as a member of the crew to protect against the existence of the unsafe condition which caused the accident.

Second, the defendant must prove that the plaintiff was injured by a dangerous condition that the plaintiff either created or knew existed and, in the proper exercise of his or her employment duties, should have controlled or protected against.

$\underline{T h i r d}$, the defendant must prove that the plaintiff's injury was caused by a knowing failure to carry out his or her responsibilities to protect against that unsafe condition. This means that the plaintiff must have known of the dangerous condition and failed to act to correct it after having a reasonable opportunity to do so, and that the accident was not caused simply by a momentary lapse of attention for his or her own safety.

5-90 Modern Federal Jury Instructions-CiviL 90.03 (Matthew Bender).

6. 46 U.S.C. $\$ 30104$.

7. 45 U.S.C. $\$ 51(2006)$.

8. Norfolk S. Ry. Co. v. Sorrell, 549 U.S. 158 (2007). See also Walker, 193 F.2d at 773-74. 
proximate cause of injury, the shipowner will be liable. ${ }^{9}$ Common-law comparative fault principles apply. ${ }^{10}$

Unlike Jones Act negligence, the seaworthiness warranty is based exclusively in federal common law, and is part of the "reverse Erie" doctrine." "Seaworthiness is a strict liability standard and requires the vessel, and its appurtenances, to be reasonably fit for the intended use of each. ${ }^{12}$ If a vessel or its equipment is unseaworthy, the owner will be liable without fault. ${ }^{13}$ When proving a claim for unseaworthiness, a seafarer must show a substantial link between his injury and the unseaworthy condition. ${ }^{14}$

Generally, in a seafarer's personal injury suit, the law favors the injured seafarer, often called a "ward of the court," 15 who has no workers" compensation benefits. ${ }^{16}$ Seafarers are in a unique employment position: a seafarer must obey orders in a quasi-military hierarchy, is wholly reliant on his employer for medical care, shelter and food, and is not free to quit and physically leave the worksite. ${ }^{17}$ Therefore, the seafarer has special remedies unavailable to other workers, and the employers have fewer defenses in personal injury suits. ${ }^{18}$ For one, the Jones Act negligence causation standard is lowered. Similarly, in an unseaworthiness action, an owner will be held

9. Gautreaux v. Scurlock Marine, Inc., 107 F.3d 331, 335 (5th Cir. 1997); but see Williams v. Long Island R.R., 196 F.3d 402, 406 (2d Cir. 1999) (rejecting an ordinary care standard in the comparative fault analysis under Gautreaux in favor of both relaxed negligence and causation standards).

10. Sorrell, 549 U.S. at 158.

11. See, e.g., S. Pacific Co. v. Jensen, 244 U.S. 205 (1917); Am. Dredging v. Miller, 510 U.S. 443 (1994).

12. See Mitchell v. Trawler Racer, Inc., 362 U.S. 539, 550 (1960).

13. See Dixon v. United States, 219 F.2d 10, 16-17 (2d Cir. 1955).

14. Spell v. Am. Oilfield Divers, Inc., 722 So. 2d 399, 402 (La. Ct. App. 1998) (“A breach of the duty of seaworthiness gives rise to a claim for general damages. The plaintiff bears the burden of proving that 'the unseaworthy condition played a substantial part in bringing about or actually causing the injury and that the injury was either a direct result or a reasonably probable consequence of the unseaworthiness.") (quoting Johnson v. Offshore Express, Inc., 845 F.2d 1347, 1354 (5th Cir. 1988)).

15. Socony-Vacuum Oil Co. v. Smith, 305 U.S. 424, 431 (1939) ("Withal, seamen are the wards of the admiralty, whose traditional policy it has been to avoid, within reasonable limits, the application of rules of the common law which would affect them harshly because of the special circumstances attending their calling. It is for this reason that remedial legislation for the benefit and protection of seamen has been liberally construed to attain that end.") (citation omitted).

16. But see Consolidated Rail Corp. v. Carlisle, 512 U.S. 532, 543 (1994) (holding "[t]hat FELA is to be liberally construed ... does not mean that it is a workers' compensation statute. We have insisted that FELA 'does not make the employer the insurer of the safety of his employees while they are on duty. The basis of his liability is his negligence, not the fact that injuries occur."').

17. Hudson Waterways Corp. v. Schneider, 365 F.2d 1012, 1014 (9th Cir. 1966).

18. Id. See also Socony, 105 U.S. at 431; and Johannessen v. Gulf Trading \& Transp. Co., 633 F.2d 653, 656 (2d Cir. 1980). 
liable if the vessel or appurtenance is not reasonably fit for its intended use, regardless of whether the owner had actual or constructive knowledge of the defective condition.

Rarely discussed is a seafarer employer's unique status. Unlike other employers, the shipowner must almost always act through its employees, over which it has little direct oversight. At the same time, the shipowner is liable for the acts of its employees and is held strictly liable for the condition of the workplace. The Primary Duty Rule recognizes the employer's situation.

As shown below, the Primary Duty Rule is not a comparative fault or assumption of the risk doctrine. Instead, the Rule focuses on the special relationship between employer and employee. It is because of this relationship that the shipowner owes special duties to its seafarer employees. However, as shown below, when a seafarer's claims against the employer are based on a breach of that special relationship, the seafarer has eliminated the duty owed, and therefore there is no basis for a suit against the owner.

In the discussion of the Primary Duty Rule, this article asserts the shipowner, forced to act through its employees by the nature of the maritime industry, cannot be held liable to those employees when an injury results to the employee from his failure to perform a primary duty of his job. To hold otherwise would require the shipowner to provide an accident free vessel, which is contrary to precedent. ${ }^{19}$

\section{WALKER V. LYKES BROTHERS}

In 1951, Judge Learned Hand, writing for the Second Circuit in Walker v. Lykes Bros. ${ }^{20}$ stated what has come to be known as the Primary Duty Rule. In that case, a ship's master ordered crewmembers to fix the broken latches of a steel filing cabinet, but the crewmembers tried and failed. The master then asked the owner's representatives at two subsequent ports to fix the latches but, "[i]n neither case did he make any effort to enforce obedience to his wishes." ${ }^{21}$ Sometime later, the drawer unexpectedly opened and injured the master.

The Walker jury found for the master after considering a jury charge that required the jurors to consider whether the plaintiff had acted as a reasonably prudent master. On appeal, Judge Hand rejected this jury charge and ordered

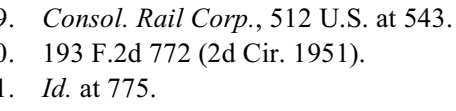


a new trial. Judge Hand delineated the difference between comparative fault and the breach of the Primary Duty Rule. He held that comparative fault is a breach of duty of care to the wrongdoer and results in a reduction of recovery; whereas the Primary Duty Rule is a breach of a duty assumed as part of employment and results in a bar to recovery. ${ }^{22}$ The court concluded that such a breach did not to result from a momentary lapse in judgment, but a violation of an affirmative duty.

The Second Circuit instructed the jury on remand to decide if plaintiff violated his duty to have his orders followed so the ship could be repaired. Since his duties included the duty to supervise, application of the Rule would preclude recovery only if he and his subordinates violated their duties. ${ }^{23}$

Implicit to the Walker holding is the recognition that a shipowner must be able to rely on its crew to remedy unseaworthy conditions that arise during a voyage; otherwise, the shipowner incorrectly would be obligated to provide an "accident free ship." 24

Notably, in Walker there was no evidence presented regarding the cause for the condition that resulted in the plaintiff's injury. The steel filing cabinet with broken latches was unseaworthy when the plaintiff captain took command, and remained unseaworthy until the cabinet sprung open and injured him. The plaintiff in Walker ultimately failed in his suit because he violated his primary duty to keep the vessel seaworthy, ${ }^{25}$ regardless of whether the shipowner was at fault in causing the latch to break.

Moreover, plaintiff's rank in Walker was relevant only in determining his Primary Duty; the rank was not dispositive in considering the application of the Rule itself. Since the plaintiff was a master, his Primary Duty, among others, was to supervise the crew. ${ }^{26}$ Had the injured plaintiff been a

22. Id. at 773 .

23. Id. at 775 ("It may be asked, why, if the plaintiff was at fault in failing on so many occasions to make any effective effort to get the catches mended, the judge ought not to have directed a verdict against him. That might have been true, if the burden had not been upon the defendant to prove not only that the plaintiff had been at fault but that his fault had been a cause of his injury, concurrent with the faults of other employees.") (emphasis added).

24. Mitchell v. Trawler Racer, Inc., 362 U.S. 539, 550 (1960). ("What has been said is not to suggest that the owner is obligated to furnish an accident-free ship. The [seaworthiness] duty is absolute, but it is a duty only to furnish a vessel and appurtenances reasonably fit for their intended use. The standard is not perfection, but reasonable fitness; not a ship that will weather every conceivable storm or withstand every imaginable peril of the sea, but a vessel reasonably suitable for her intended service.").

25. Walker, 193 F.2d at 773.

26. Id. (" $[\mathrm{I}] \mathrm{t}$ is well settled that the duty of the master in the case of damage to the ship is to do all that can be done towards bringing the adventure to a successful termination; to repair the ship, if there be a reasonable prospect of doing so at an expense not ruinous; just as it is his duty to care for the cargo, or 
crewmember with maintenance duties, his Primary Duty would have been to follow the captain's orders and fix the latch. If the crewmember had not followed those orders and been injured by the failing latch, he would have been barred from recovery under the Primary Duty Rule.

As will be discussed below, Judge Hand based his decision on several prior cases; therefore, the Primary Duty Rule did not originate with the Second Circuit's decision in Walker.

\section{PRE-WALKER CASES}

The genesis of Walker and the Primary Duty Rule grew from different sources over time. For example, in 1891, the federal district court in Maine examined the 1884 Limitation Act and held that a shipowner is vicariously liable for the tortuous acts of its master. ${ }^{27}$ Moreover, in 1906, the Sixth Circuit, in Gesswine discussed whether a train operator's violation of a safety statute was negligence per se when the train ran over and killed another employee at a crossing. ${ }^{28}$ Since the decedent was not a member of the class the rule was designed to protect (i.e., the travelling public), the railway company was not negligent. ${ }^{29}$ The court indicated the decedent might have violated his duty to be aware of his surroundings at a crossing. ${ }^{30}$ These cases, among others, established an owner's vicarious liability for the acts of its employees, and that employees have duties that are relevant when considering whether an employee can recover from the owner for an injury.

The Sixth Circuit in Niebel discussed apportioning fault among coemployees who violated their respective duties and caused an accident. ${ }^{31}$ In that case, two trains collided at a crossing. ${ }^{32}$ Niebel, the flagman on one of the trains, did not perform his duty to warn the oncoming train, but the engineer on the approaching train failed in his duties to signal and slow as he approached the crossing. ${ }^{33}$ Because both men violated their duties, the court

not to overload the ship. Thus, if the plaintiff failed to repair the catches, although he was able to do so, his failure was not only "contributory negligence" in the first sense, but also a breach of his duty to the defendant which barred his recovery absolutely.") (citations omitted).

27. The Giles Loring v. Webster, 48 F. 463 (D. Me. 1891).

28. Norfolk \& W. Ry. Co. v. Gesswine, 144 F. 56 (6th Cir. 1906).

29. Id. at $57-58$.

30. Id. at 58 (finding the area where decedent had been working was "manifestly, a place of danger[,]" and the employees were expected to be alert and protect themselves from approaching trains).

31. New York, Chi. \& St. L. R.R. Co. v. Niebel, 214 F. 952 (6th Cir. 1914).

32. Id. at 954 .

33. Id. 
remanded the case to the jury for a consideration of comparative fault. ${ }^{34}$ Niebel recognized that violation of a duty can result in vicarious liability for the employer and comparative fault for the employee..$^{35}$

In Linkous, an engineer died in a collision after he failed to stop his train, as ordered, so another train could pass. ${ }^{36}$ The engineer's estate claimed that the conductor, fireman, and front brakeman of decedent's train failed to intervene and avoid the accident. ${ }^{37}$ The written orders to "meet and pass" were found on their dead bodies. ${ }^{38}$ There was no evidence to explain their disregard of the order. ${ }^{39}$ Defendant's rail company rule stated that engineers and conductors were responsible for the safety of trains and had a duty to enforce the company rules. ${ }^{40}$ Plaintiff claimed the failures of decedent's coworkers to perform their duties were the proximate cause of his death. ${ }^{41}$

The district court denied defendant's motion for a directed verdict. ${ }^{42}$ The Sixth Circuit reversed. ${ }^{43}$ The court held there was no evidence for the jury to find defendant was at fault because one of decedent's fellow employees violated a primary duty and caused his death. ${ }^{44}$ In this holding, the court anticipated the Primary Duty Rule and discussed it in terms of defendant's potential liability when an employee violates his duty and causes injury to another employee. ${ }^{45}$ Since all the witnesses in that case had died, there was no evidence indicating any of the men violated their duties. ${ }^{46}$ However, the court

34. Id. at 956-57 ("Under the rule of comparative negligence, the jury is entitled to consider all the circumstances which characterize the negligence of either party and which tend to fix the quantity and quality of that negligence in its relation to the sum total of the negligence of both parties. Even though the negligence of either party clearly appears, all circumstances of aggravation or of mitigation must be considered; and in view of some of the evidence found in the record regarding the proper practice under this rule, it cannot be said as matter of law that its nonobservance could have no effect in lessening the quantum of Niebel's fault.").

35. Id. at 995 .

36. Virginian Ry. Co. v. Linkous, 230 F. 88 (4th Cir. 1915).

37. Id. at 90 .

38. Id.

39. Id.

40. Id. at 91-92.

41. Id.

42. Linkous, 230 F. at $92-93$.

43. Id.

44. Id.

45. Id. at 93. ("While the Employers' Liability Act was manifestly intended to modify the law as it formerly existed so as to materially benefit those who might be injured in the future, by abolishing the harsh rule known as the 'Fellow-Servant Doctrine,' yet it cannot be reasonably insisted that it was the purpose of the act to afford relief where one's injury is due solely to his own reckless and indifferent conduct.").

46. $I d$. 
acknowledged the potential for liability had decedent's coworker violated a primary duty and caused his coworker's death. ${ }^{47}$

Walker cited Wiles $^{48}$ as the first case to state the Primary Duty Rule. In Wiles, the administrator of a brakeman's estate brought a wrongful death action against the railway employer. ${ }^{49}$ The issue before the Supreme Court was whether decedent brakeman's neglect barred the suit..$^{50}$ The Court held the brakeman's violation of a duty precluded any recovery by his estate. ${ }^{51}$

In Wiles, The Minnesota Supreme Court had applied the doctrine of res ipsa loquitur because it found the employer had exclusive control over the instrumentality that caused the incident - the broken drawbar that stopped the section of the train prior to the incident. ${ }^{52}$ The Supreme Court reversed and declined to apportion fault under res ipsa loquitur, instead finding that decedent's violation of his duty precluded his estate's recovery. ${ }^{53}$

Wiles involved the brakeman's duties as derived from his job title. ${ }^{54} \mathrm{He}$ was not in charge of the train, nor did he specifically volunteer for the duty at issue. $^{55}$ His suit failed because his claim was based upon an incident occasioned by his failure to perform a function that was part of his job, namely, to flag a warning to approaching trains after some of the cars of his train stopped (due to the broken drawbar). ${ }^{56}$ Importantly, in Wiles, the employer was at fault in creating the situation at issue.$^{57}$ However, plaintiff's violation of his duty negated his recovery. ${ }^{58}$

47. Id.

48. Great. N. Ry. Co. v. Wiles, 240 U.S. 444 (1916).

49. Id.

50. $I d$.

51. Id. at 448. ("In the present case there was nothing to extenuate Wiles' negligence, there was nothing to confuse his judgment or cause hesitation. His duty was as clear as its performance was easy. He knew the danger of the situation and that it was imminent; to avert it he had only to descend from his train, run back a short distance, and give the signals that the rules directed.").

52. Id. at 447 .

53. Id. at 448 ("There is no justification for a comparison of negligences or the apportioning of their effect." Decedent had "a duty not only to himself, but to others. The rules of the company were devised for such a condition and provided for its emergency. [Decedent] knew them and he was prompted to the performance of the duty they enjoined (the circumstances would seem to have needed no prompting) by signals from the engineer when the train stopped. He disregarded both.") (emphasis added).

54. Wiles, 240 U.S. at $445-47$.

55. Id.

56. Id. at 448

57. $I d$.

58. Id. 
The court in Turner ${ }^{59}$ addressed a suit by the estates of a ship's master and fireman arising from a boiler explosion on a derrick. The evidence showed the fireman did not properly plug the boiler that later exploded and killed the crew. ${ }^{60}$ The court dismissed the causes of action arising from the deaths of both men. ${ }^{61}$

In that case, the court barred the master from recovering damages because he failed to supervise a low-level fireman.$^{62}$ The fireman's suit failed because he did not perform his duty properly to plug the boiler. ${ }^{63}$ The court ruled that the owner could not be held liable to a crewmember whose breach of a duty was the basis of the employee's claim against the owner. ${ }^{64}$ Walker cited Turner as a basis for the Primary Duty Rule. ${ }^{65}$

In another case cited by Walker, the Supreme Court in Frese,${ }^{66}$ reaffirmed its previous holdings that a violation of duty would preclude a suit for resulting injuries and death. In Frese, a FELA case, the estate of an engineer killed in a train collision argued the owner should be liable for the negligence of the train's fireman, the engineer's subordinate. ${ }^{67}$ The Court held that engineer's violation of a state statute that required a train to make a full stop

59. Patton-Tully Transp. Co. v. Turner, 269 F. 334 (6th Cir. 1920).

60. Id. at 336 .

61. Id. at 343 .

62. Id.

63. Id. at 339 .

64. The Turner court stated:

[T] here cannot be liability by the owner to the master to keep the boat safe against the master's own negligence. The same act by the master, which made the boat liable to the seamen because his act was the owner's act, cannot make the boat or the owner liable to him. As between him and the owners, his act is his, not theirs. No liability reaches the owners in favor of the seamen, except through the master as a conduit; and he cannot be the conduit of his own wrong for his own benefit. In the common relation of master and servant, we cannot suppose that the rule of respondeat superior makes the master liable to the servant for whose negligent act the master must (as to others) respond.

Liability as to the fireman might well be denied on the same theory as that just stated with regard to the master; but more controlling is the fact that the fireman's carelessness in operation was surely the primary cause of the explosion. He knew of whatever degree of unsafety there was, he knew of the added duty thereby put upon him to watch the water, and he failed in that duty. On him, more than in any other one place, rests the blame for the ensuing death and destruction. He cannot be heard to say that a boiler defect, consisting only in the lack of a safeguard against his carelessness, and which defect would have been harmless, except for his negligence, was, as to him, an efficient contributing cause of the explosion.

Id. at 342 (emphasis added).

65. Walker, 193 F.2d at 774.

66. Frese v. Chi. Burlington \& Quincy R.R., 263 U.S. 1, 3 (1923).

67. Id. at 1 . 
at a crossing amounted to a breach of his primary duty and barred his suit. ${ }^{68}$ The Court also discussed the Primary Duty Rule's application based on the failure of the subordinate fireman. ${ }^{69}$

In Mc Calmont v. Pennsylvania Railroad Co., the Sixth Circuit proscribed a suit by a train's engineer injured when he violated his duty and stood between train cars as they coupled. ${ }^{70}$ The train company's negligence resulted in a defective coupling, which plaintiff was trying to remedy when he was caught between the train cars in a subsequent coupling. ${ }^{71}$ The Court, citing Wiles, found that plaintiff violated his duty to work safely, and the injury would not have occurred if he had properly performed his duties. ${ }^{72}$ The Court said the owner's negligence, if any, was a remote cause of the incident and plaintiff's violation of his duty was the intervening and sole cause of his injury. ${ }^{73}$

In another case cited by Walker as a basis for its holding, the Supreme Court in Davis ${ }^{74}$ ruled against plaintiff in a suit by an engineer's estate. In that case, the engineer moved his train forward despite standing company orders to stop in the situation he faced, and despite a contrary order by the train's conductor. ${ }^{75}$ The Court reasoned the estate should not recover for a death

68. Id. at $2-3$.

69. The court stated:

$[T]$ he statute makes it the personal duty of the engineer positively to ascertain that the train can safely resume its course. Whatever may have been the practice, he could not escape this duty, and it would be a perversion of the Employers' Liability Act to hold that he could recover for an injury primarily due to his failure to act as required, on the ground that possibly the injury might have been prevented if his subordinate had done more.

Id. at 3 (internal citation omitted) (emphasis added).

70. McCalmont v. Pa. R.R. Co., 283 F. 736 (6th Cir. 1922).

71. Id. at 737 .

72. The court stated:

Wiles knew, as McCalmont did, that in the regular and ordinary operation of the road such a collision as did take place was liable to occur at any moment. It was Wiles' clear duty, as it was McCalmont's, to take a certain prescribed step which, if taken, would prevent the collision. In each case there was neither negligence in bringing about the collision nor cause for the collision, except the failure of the man hurt to take that step which it was his duty to take to protect himself and others. If Wiles had gone back with his flag, as his duty required, that collision probably might have been avoided. If McCalmont had set out his flag as his duty required, it is even more probable that there would have been no collision. Our affirmance of the judgment below could safely be rested on the Wiles Case alone.

Id. at 741-42 (emphasis added).

73. Id. at 741

74. Davis v. Kennedy, 266 U.S. 147 (1924).

75. Id. at 148 . 
brought about by a condition the decedent caused in violation of his duties. ${ }^{76}$ The Court also rejected the estate's argument that subordinate employees could have prevented the accident. ${ }^{77}$ Citing Frese, the Davis Court held the violation of the decedent's primary duty precluded the suit. ${ }^{78}$

Walker also referenced Blunt as a basis for the Primary Duty Rule. In that case, a low-level employee, a watchman, failed to keep a lookout at a crossing and caused a truck and train collision that resulted in his injury. ${ }^{79}$ At the time of the collision, the watchman was in a shanty due to bad weather, instead of standing at the crossing as was his duty ${ }^{80}$ Notably, the company had provided the shanty to the watchman to shield him from bad weather. ${ }^{81}$ This, however, did not relieve him of his duty since he could use the shanty only when that use was consistent with his duty to stand watch at the crossing. ${ }^{82}$ The Court found the watchman's failure to keep a lookout was a violation of his "paramount duty" and the sole cause of the collision. ${ }^{83}$ The court affirmed the directed verdict for defendant. ${ }^{84}$

In Caldine, also cited by Walker, a conductor died in a collision after he signaled a train to proceed contrary to written company guidelines. ${ }^{85}$ The Supreme Court rejected the argument that his subordinates were negligent in following the conductor's orders, or in failing to warn him of the danger. ${ }^{86}$

76. Id. at $148-49$

77. $I d$.

78. Id. ("It was the personal duty of the engineer positively to ascertain whether the other train had passed. His duty was primary as he had physical control of No. 4, and was managing its course. It seems to us a perversion of the statute to allow his representative to recover for an injury directly due to his failure to act as required on the ground that possibly it might have been prevented if those in secondary relation to the movement had done more.") (emphasis added).

79. Blunt v. Pa. R.R. Co., 9 F.2d 395 (6th Cir. 1925).

80. Id.

81. $I d$.

82. Id.

83. Id. at 396.

84. The court held:

It was the personal duty of plaintiff to keep a lookout at the crossing, and to warn those about to use it of any trains that were approaching. The performance of this duty necessarily required that he discover the train in time to protect himself and warn others. The evidence shows that, owing to weather conditions, he could not see the train from inside the shanty, but, if he had remained outside, could have seen it in time to have warned the driver and prevented the collision. He had no right to use the shanty, except as he could do so consistently with his duty as watchman. It was his failure to perform this paramount duty that was the sole proximate cause of the collision. Id. at 395-96.

85. Unadilla Valley Ry. Co. v. Caldine, 278 U.S. 139 (1928).

86. Id. at $141-42$. 
Since he was in command, his primary duty was to supervise the crew. ${ }^{87}$ Therefore, he could not blame his crew for following his order and thereby violating the company rules. ${ }^{88}$

Another case cited by Walker is Hylton, out of the Sixth Circuit. ${ }^{89}$ There, an engineer disregarded written instructions and died in the ensuing derailment. ${ }^{90}$ The defendant employer was also at fault for failing to send a flagman to warn the approaching train of the track work ahead. ${ }^{91}$

The court cited Wiles, Frese and Davis ${ }^{92}$ and stated it was not considering decedent's action in a comparative fault analysis; he did not neglect a duty to himself, he failed to perform an affirmative "imperative" duty required as an employee. ${ }^{93}$ His violation was the "sole efficient cause" ${ }^{94}$ of the incident and

87. Id.

88. The Court said:

It seems to us that [plaintiff], or one who stands in his shoes, is not entitled as against the Railroad Company that employed him to say that the collision was due to anyone but himself. He was in command. He expected to be obeyed, and he was obeyed as mechanically as if his pulling the bell had itself started the train. In our opinion he cannot be heard to say that his subordinate ought not to have done what he ordered. He cannot hold the Company liable for a disaster that followed disobedience of a rule intended to prevent it, when the disobedience was brought about and intended to be brought about by his own acts. Still considering the case as between the [defendant] and [plaintiff], it seems to us even less possible to say that the collision resulted in part from the failure to inform [plaintiff] of the telephone [warning] from train No. 15. A failure to stop a man from doing what he knows that he ought not to do, hardly can be called a cause of his act. [Plaintiff] had a plain duty and he knew it. The message would only have given him another motive for obeying the rule that he was bound to obey.

Id. at 141-42 (citation omitted).

89. S. Ry. Co. v. Hylton, 37 F.2d 843 (6th Cir. 1930).

90. Id. at $843-44$.

91. Id.

92. Id. at 845 ("In Frese v. Chicago, etc., R. Co., 263 U.S. 1, 44 S. Ct. 1, 2, 68 L. Ed. 131, there was a collision at a grade crossing of two railroads. One of the engineers was killed, and this action against his employer resulted. His contributory negligence was not involved. It was his duty under the rules (and it was no different duty because it was also required by statute) to bring his train to a full stop and ascertain that the way was clear before proceeding ...") (emphasis added).

93. The court stated:

The controlling principle, though arising under different facts, is stated in Great Northern Railway Co.v. Wiles, 240 U.S. 444. A freight train broke in two, due, as the court assumes, to the company's negligence. Wiles was the rear brakeman. It was his duty to go back and flag the following train. He did not do so, and he was killed in the ensuing rear-end collision. His representatives brought the suit. In reversing the judgment for plaintiff, the Supreme Court said: "There is no justification for a comparison of negligences or the apportioning of their effect. In the present case there was nothing to extenuate Wiles' negligence; there was nothing to confuse his judgment or cause hesitation. His duty was as clear as its performance was easy.

Id. (emphasis added).

94. Id. ("In this situation we think it clear that Hylton's general disobedience of the 19 order and his specific and voluntary release of control because he had misjudged the distance of the danger 
barred his estate's recovery of damages.$^{95}$ Hylton added a temporal immediacy aspect to the rule, describing the duty the brakeman violated as an "imperative duty." 96

The court reemphasized a supervisory employee's primary duty is to ensure his or her subordinates carry out their assignments. ${ }^{97}$ Moreover, the Court cited Caldine and anticipated and distinguished Tiller, infra, and similar arguments, that the Primary Duty Rule is a doctrine of comparative fault. ${ }^{98}$ In so doing, the court also held a violation of a Primary Duty renders immaterial fault by a co-employee that otherwise would be imputed to the employer. ${ }^{99}$ The Sixth Circuit added that the Primary Duty Rule applies when there is negligence by another employee that is not a direct subordinate to the plaintiff. ${ }^{100}$

constituted the sole efficient cause of the disaster, and the absence of any further second flag cannot be treated as a substantially contributing cause. The recent decisions of the Supreme Court require this conclusion.")

95. Hylton, $37 \mathrm{~F} .2 \mathrm{~d}$ at 844 ("The uncontradicted testimony from witnesses on both sides is that this order made it Hylton's imperative duty to hold his train during this mile under such control that he could at any time stop within half the distance of his clear vision ahead.") (emphasis added).

96. $I d$.

97. Id. at 845 . ("Moreover the statute makes it the personal duty of the engineer positively to ascertain that the train can safely resume its course. Whatever may have been the practice he could not escape this duty, and it would be a perversion of the Employers' Liability Act [45 USCA § 53] to hold that he could recover for an injury primarily due to his failure to act as required, on the ground that possibly the injury might have been prevented if his subordinate had done more.") (quoting Frese).

98. The Hylton court stated:

The Supreme Court held that there was no cause of action, saying: "The phrase of the statute, 'resulting in whole or in part,' admits of some latitude of interpretation and is likely to be given somewhat different meanings by different readers. Certainly the relation between the parties is to be taken into account. It seems to us that Caldine or one who stands in his shoes is not entitled as against the Railroad Company that employed him to say that the collision was due to any one but himself. He was in command. He cannot hold the Company liable for a disaster that followed disobedience of a rule intended to prevent it, when the disobedience was brought about by his own acts. A failure to stop a man from doing what he knows that he ought not to do, hardly can be called a cause of his act. Caldine had a plain duty and he knew it. The message would only have given him another motive for obeying the rule that he was bound to obey." In comparing the facts of the Caldine Case with those of the present case, we find no substantial distinction. The second flag would only have given Hylton another motive for obeying the rule that he was bound to obey." See Norfolk, etc., Co. v. Gesswine (C.C.A. 6) 144 F. 58; Virginian R. Co. v. Linkous (C.C.A. 4) 230 F. 88; Copeland v. Hines, supra; Blunt v. Pa. R. Co. (C.C.A. 6) 9 F.(2d) 395; Unadilla Valley R. Co.

v. Dibble (C.C.A. 2) 31 F.(2d) 239

Id. at 846 .

99. $I d$.

100. Id. ("The suggested distinction, as to the Frese and Davis Cases, that the concurring negligence which is disregarded in those cases was that of an associate or subordinate while Majors and Hylton were in separate departments, cannot survive the Unadilla Case, for there the assumed — but immaterial—further negligence was that of the station agent."). 
The Walker Court also cited the Second Circuit in Paster. ${ }^{101}$ In that case, a low-level employee's violation of his duty precluded his suit against his employer. ${ }^{102}$ Plaintiff was an assistant yardmaster of a rail yard and he was hit by a rail car after he directed the cars contrary to company guidelines. ${ }^{103}$ The Second Circuit cited the foregoing Supreme Court and Sixth Circuit cases and decided the case at issue involved neither assumption of the risk nor contributory negligence. ${ }^{104}$ Instead, the court focused on the type of duty the plaintiff breached - there a company guideline for his safety - and found his violation of that duty negated his recovery. ${ }^{105}$ The court left it to the Supreme

101. Paster v. Pa. R.R., 43 F.2d 908 (2d Cir. 1930).

102. Id.

103. $I d$.

104. The court said:

We should have been disposed to call such inattention contributory negligence which could go only in mitigation of damages, had it not been for those decisions of the Supreme Court to which we shall refer. Every servant is in general subject to a duty to take care for his own safety, and we do not understand that in general it makes a difference that the master may have established an express standard, Canadian Pacific Ry. Co. v. Elliott, 137 F. 904 (C.C.A. 2); Id. (C.C.A.) 161 F. 250. Even after the Federal Employers' Liability Act, when the distinction between contributory negligence and assumption of risk first became important, it was supposed that the violation of a rule, was only contributory negligence. New York, etc., R. Co. v. Niebel, 214 F. 952 (C.C.A. 6). Moreover, such cases as Great Northern Ry. Co. v. Wiles, 240 U.S. 444, 36 S. Ct. 406, 60 L. Ed. 732, and McCalmont v. Pennsylvania R. Co., 283 F. 736 (C.C.A. 6), though often cited as exceptions, do not strictly involve contributory negligence at all, because in those the servant was aware of the earlier fault, and his subsequent disregard of the rule brought the case among those where the last wrongdoer is wholly liable, if he has had opportunity to shape his conduct upon existing facts, however caused.

Id. at 910 .

105. The court held:

In a series of cases, however, under the Federal Employers' Liability Act, the Supreme Court has modified this rule, as we understand it (Frese v. C., B. \& Q. Ry. Co., 263 U.S. 1, 44 S. Ct. 1, 68 L. Ed. 131; Davis v. Kennedy, 266 U.S. 147, 45 S. Ct. 33, 69 L. Ed. 212; Unadilla, etc., Ry. Co. v. Caldine, 278 U.S. 139, 49 S. Ct. 91, 73 L. Ed. 224); and the lower courts have followed (Southern Ry. Co. v. Hylton, 37 F.(2d) 843 (C.C.A. 6); Unadilla, etc., Ry. v. Dibble, 31 F.(2d) 239 (C.C.A. 2 ). In these it was held that the disregard by a servant of specific orders or standing rules, promulgated for his own safety, will bar his recovery though the injury was due as well to the fault of other servants. Just how far this may go we do not know; possibly it will be confined to rules which provide for a specific contingency, but apparently it goes at least so far. The decisions concerned engineers, conductors or the like, but if this be material, Paster certainly falls within the class, for he was in charge of the repair. It is not dependent upon the injured person's being in command of those on whose faults he relies to establish liability, Southern Ry. Co. v. Hylton. In spite of the fact, therefore, that we held in Canadian Pacific Railway v. Elliott, that the breach of this very rule was contributory negligence, it seems to us that we are now bound to say that it defeats liability altogether. We must leave it to the Supreme Court to indicate how the doctrine is to be demarked, and whether the breach of any rule is a defense.

Id. at 910 . 
Court to determine whether the Primary Duty Rule applied only to certain types of rules, i.e., a safety rule or other kinds of rules. However, the court said plaintiff's rank was not dispositive when considering whether the Primary Duty Rule governs a case. ${ }^{106}$

In Southern Railway Co. v. Youngblood, a train engineer's estate sued for the damages caused by his death in a train collision. ${ }^{107}$ The two trains crashed when one operator disregarded a company order regarding proper communications. ${ }^{108}$ However, the decedent disobeyed a company order pertaining to safe passage of trains. ${ }^{109}$ The Supreme Court held his estate could not recover for his death. ${ }^{110}$ If he had performed his duty he would not have died. Therefore, his estate could not recover. ${ }^{111}$ Walker cited Youngblood as a basis for the Primary Duty Rule.

In Rocco, ${ }^{112}$ another case cited by Walker, the estate of a track inspector sued after he was run over by an approaching train at a blind turn as he was riding his track-inspecting tricycle. The decedent inspector failed to perform his duty to check the tracks were clear. ${ }^{113}$ The Court found decedent's violation of his duty might not have been the primary cause of his death, which may have been concurrently caused by the negligence of operator of the approaching train. ${ }^{114}$ The Court therefore left to the jury the apportionment of fault between decedent and the operator of the train. ${ }^{115}$

106. $I d$.

107. S. Ry. Co. v. Youngblood, 286 U.S. 313 (1932).

108. Id. at 314-15.

109. Id. at 315-16.

110. The court said:

The case comes to this: that respondent's intestate had clear and definite orders which if obeyed would have avoided the accident and the disobedience whereof was the sole efficient cause of his death. As said in Unadilla Valley Ry. Co. v. Caldine, 278 U.S. 139, 142 (1928):

A failure to stop a man from doing what he knows that he ought not to do hardly can be called a cause of his act. Caldine had a plain duty and he knew it. The message would only have given

him another motive for obeying the rule that he was bound to obey. Id. at 317

111. Id. ("This crass disobedience of operating orders was the sole cause of the intestate's death. If the order respecting the passing of the trains had been made as a five-copy order the operator at Orangeburg would merely have handed the crew two copies in the same words as those of the order they then held, which then governed their conduct.").

112. Rocco v. Lehigh Valley R.R. Co., 288 U.S. 275 (1933).

113. Id. at 276-77.

114. Id. at 279-80 (Here, however, the violation of the rule was not the primary cause of the accident. Even if he followed the rule, the accident could have occurred in the same circumstances. It was still a question for the jury whether decedent and/or the oncoming train was negligent.).

115. Id. at 277-79 ("The questions presented are whether under the circumstances the respondent owed the decedent any duty to warn him of the approach of the train, or to keep a lookout for him; and 
The Court did, however, discuss the Primary Duty Rule and stated that the violation of any primary duty could be the basis of the defense, including a plaintiff's violation of a safety rule. ${ }^{116}$ Here, however, the rule at issue left decedent with discretion in the manner he could perform his duty. Strictly viewed, he may not have violated the duty depending how the rule was interpreted. Therefore, the court treated the matter as a comparative fault case in which the employer's fault may have played "a" part in the incident. ${ }^{117}$

Although not cited by Walker, the Court's decision in Socony ${ }^{118}$ is relevant to the within discussion. In that case, the Court reaffirmed that seafarers are wards of the Admiralty courts and discussed assumption of the risk as a defense to a Jones Act suit. ${ }^{119}$ There, an oiler fell on a defective step while changing a bearing. ${ }^{120}$ The seafarer had used the step though he knew it was broken and could have used a safer alternate. ${ }^{121}$ The Court held a seafarer would not be precluded from recovery based on his negligent choice of the defective step that caused his injury. ${ }^{122}$ The case relegated assumption of the risk to a factor in a comparative fault analysis, rather than a complete bar to recovery.

Soon after, the Fifth Circuit in Atchinson, also cited by Walker, held that an engineer injured in a collision was barred from recovery because he violated a specific company rule when he operated his train at an excessive speed. ${ }^{123}$ The Fifth Circuit distinguished between a violation of a "general" company rule which would not, in itself, amount to neglect, ${ }^{124}$ and a violation of a "specific" or "peremptory" rule, there, a speed limit, which would qualify as neglect. ${ }^{125}$ However, the court held that if plaintiff's neglect was not the sole cause of his injury and a co-employee shared concurrent fault, the jury

\footnotetext{
whether Rocco's disobedience of the rule was in such sense the primary cause of his death as to render immaterial any neglect on the part of the motorman. The Court of Appeals decided both questions against the petitioner.").

116. Id. at $278-80$.

117. Id.

118. Socony-Vacuum Oil Co. v. Smith, 305 U.S. 424 (1939).

119. Id.

120. Id. at $426-27$.

121. Id. at 429 .

122. $I d$. at 433

123. Atchison R.R. v. Ballard, 108 F.2d 768 (5th Cir. 1940).

124. $I d$. at 771 ("[A] violation of company rules for the conduct of its employees, general in terms, will not ordinarily constitute negligence as matter of law.").

125. Id. ("A violation of specific rules though, will constitute negligence just as their observance by others, will, in relation to the violator, constitute, due care.") (citation omitted).
} 
should apportion damages. ${ }^{126}$ In that case, the train's fireman may not have kept a proper lookout and jointly may have caused the collision. ${ }^{127}$

In Bowser, the Third Circuit discussed a train collision resulting in the deaths of the witnesses to the incident. ${ }^{128}$ In that case, decedent engineer operated his train in contravention to the track signals and caused the resulting collision. ${ }^{129}$ The fireman and brakeman in the engine compartment each had a duty to inform the engineer of oncoming signals, as it was the decedent engineer's duty to call out the signals for the brakeman and fireman. ${ }^{130}$ Each man had a duty to answer the calls. The court left to the jury a determination the degree of fault by the three men, and the resulting apportionment of damages. ${ }^{131}$

In Van Derveer, another case cited by Walker, the Second Circuit discussed the Primary Duty Rule and specifically said the Rule precludes a suit when the plaintiff violates his or her employment duty. ${ }^{132}$ The court concluded that an employee who breached a company rule could not recover for a resulting injury. ${ }^{133}$ The Rule applied when the employee violated an express company rule, even when a co-employee may have contributed to the incident through a concurrent violation of a rule. ${ }^{134}$

In that case, the employee could not recover when he breached his obligation to address the situation that caused his injury. ${ }^{135}$ The court

126. $I d$. at 770 .

127. Id. at 771 .

128. Bowser v. Baltimore \& O.R. Co., 152 F.2d 436 (3d Cir. 1945).

129. Id. at $437-38$.

130. $I d$.

131. Id. at 440 .

132. Van Derveer v. Delaware, L. \& W.R. Co., 84 F.2d 979 (2d Cir. 1936).

133. $I d$.

134. Id. at 981 ("When an injury to one employee results from the combined fault of himself and a fellow-worker, the damages are divided, 45 U.S.C. $\$ 53$, but an exception has grown up when the injured employee's fault is the violation of a rule or an express instruction.").

135.

$[T]$ he doctrine is merely that if the injured employee has contributed to his injury by the breach of a rule or an instruction ad hoc, he cannot recover. By reason of the phrase, "contributory negligence," in section 53 (45 U.S.C.), it might have been possible to put such an exception [negligence by the employer] on the ground that indiscipline is not "negligence," a word more properly confined to inattention to one's safety. But that has never been suggested as the reason, and we should hesitate to ascribe it to the court. Moreover, it is not in any case our province to do more than ascertain the extent of the doctrine. We are satisfied that it speaks generally, whatever the reason, and that the judge was right to direct a verdict.

Id. at 982 (emphasis added). 
explicitly rejected the argument that the plaintiff's rank was a factor in deciding whether his claim is barred under the Primary Duty Rule. ${ }^{136}$

In Van Derveer, the plaintiff was the estate of a deceased freight conductor who had been in charge of a train that collided with another train. ${ }^{137}$ Decedent violated a company rule to stop and signal, and the crew on the oncoming train also violated its duty to stop. ${ }^{138}$ The trial court found decedent's violation of his duty negated any recovery by his estate, and the Second Circuit affirmed. ${ }^{139}$

\section{The TILLER Holding IN 1943}

Among the cases that preceded Walker is the Supreme Court's Tiller. ${ }^{140}$ Though Walker did not mention Tiller, the latter cannot be overlooked when discussing the Primary Duty Rule. In Tiller, the Supreme Court said that the 1939 amendments to FELA which negated assumption of the risk as a defense, "swept into discard" defenses based on that assumption of the risk. ${ }^{141}$ Some courts, notably the Fifth Circuit, interpreted this language to mean the Primary Duty Rule, mentioned by name in Tiller, had been overruled, or at least severely limited. ${ }^{142}$ Other courts, such as Walker decided in 1951, continued Hylton)

136. Id. at 981-82 (citing, among others, Frese, Caldine, Rocco, Paster, Davis, Youngblood and

137. Id. at 980 .

138. Van Derveer, 84 F.2d at $980-81$.

139. Id. at $981-82$.

140. Tiller v. Atl. Coast Line R.R. Co., 318 U.S. 54 (1943).

141.

Aside from the difficulty of distinguishing between contributory negligence and assumption of risk many other problems arose. One of these was the application of the "primary duty rule" in which contributory negligence through violation of a company rule became assumption of risk. Unadilla Valley Ry. Co. v. Caldine, 278 U.S. 139; Davis v. Kennedy, 266 U.S. 147.

In thousands of cases the doctrine is complicated by "promise to repair," "peremptory order," and other special incidents. The "simple tool" doctrine also arose as an exception. The "promise to repair" aspect of the question is further confused by two superimposed theories; that the employee may rely upon such promise for a reasonable time and, next, that if the danger was so manifest that no reasonable person would act upon such promise, then assumption of risk is reestablished.

It was this maze of law which Congress swept into discard with the adoption of the 1939 amendment to the Employers' Liability Act, releasing the employee from the burden of assumption of risk by whatever name it was called. The result is an Act which requires cases tried under the Federal act to be handled as though no doctrine of assumption of risk had ever existed. Id. at 63-64 (emphasis added).

142. See, e.g., Dixon v. United States, 219 F.2d 10 (2d Cir. 1955); Johnson v. Offshore Express, Inc., 845 F.2d 1347 (5th Cir. 1988); Schlichter v. Port Arthur Towing Co., 288 F.2d 801 (5th Cir. 1961); Krall v. United States, 1990 U.S. Dist. LEXIS 15998 (E.D. La. 1990). 
to enforce the Primary Duty Rule. ${ }^{143}$ Though not cited by these latter courts, the concurrence in Tiller offered reasoning for the continued viability of the Primary Duty Rule after Congress removed the Assumption of the Risk defense from FELA, and thus, the Jones Act. ${ }^{144}$

In his Tiller concurrence, Justice Frankfurter differentiated between the different types of assumption of the risk that are in FELA. ${ }^{145}$ Before the 1939 amendments, assumption of the risk was not a defense to an employee's lawsuit if the employer had violated a safety statute. ${ }^{146}$ In 1939, FELA eliminated assumption of the risk as a defense when employer negligence caused the injury. ${ }^{147}$

Justice Frankfurter said that risk is inherent in the modern industrial workplace. ${ }^{148}$ Even with the 1939 amendments, employees cannot recover based on the risks of their employment when the employer is not at fault. ${ }^{149}$

143. See, e.g., Walker, 193 F.2d 772.

144. Tiller, 318 U.S. at $68-71$.

145. Id.

146. Id. at 70. ("Our present concern is with the Federal Employers' Liability Act. Prior to 1939, the only inroad made by the Act upon the doctrine of 'assumption of risk' as a defense to liability arising from negligence was that in any action brought by an employee, he 'shall not be held to have assumed the risks of his employment in any case where the violation by said common carrier of any statute enacted for the safety of employees contributed to the injury or death of such employee."' (quoting FELA)).

147. Id. at 70-71. ("This was the unfortunate situation which the 1939 amendment, the Act of August 11,1939 , c. 685,53 Stat. 1404 , sought to remedy. To $\S 4$ was added the provision that in any action brought by an employee he 'shall not be held to have assumed the risks of his employment in any case where such injury or death resulted in whole or in part from the negligence of any of the officers, agents, or employees of such carrier.' The effect of this provision is to make it clear that, whatever other risks an employee may assume, he does not 'assume the risk' of the negligence of the carrier or its other employees. Once the negligence of the carrier is established, it cannot be relieved of liability by pleading that the employee 'assumed the risk."')

148.

In the setting of a totally different set of circumstances, "assumption of risk" has a totally different meaning. Industrial enterprise entails, for all those engaged in it, certain hazards to life and limb which no amount of care on the part of the employer can avoid. In denying recovery to an employee injured as a result of exposure to such a hazard, where the employer has in no sense been negligent or derelict in the duty owed to his employees, courts have often said that the employee "assumed the risk." Here the phrase "assumption of risk" is used simply to convey the idea that the employer was not at fault and therefore not liable.

Id. at 69 .

149.

But the 1939 amendment left intact the foundation of the carrier's liability-negligence. . . . Congress has to some extent alleviated the doctrines of the law of negligence as applied to railroad employees. By specific provisions in the Federal Employers' Liability Act, it has swept away "assumption of risk" as a defense once negligence is established. But it has left undisturbed the other meaning of "assumption of risk," namely, that an employee injured as a consequence of being exposed to a risk which the employer in the exercise of due care could not avoid is not entitled to 
Thus, Justice Frankfurter interpreted the amendment to mean that assumption of the risk is not a defense only when an employer's negligence caused the incident. ${ }^{150}$ The Justice added that an employer will not be held liable for the "usual risks" inherent to the job at hand. ${ }^{151}$

The facts of Tiller dictated the Court's decision to remand to the jury the question of whether the employer had been negligent. ${ }^{152}$ In Tiller, a policeman at a rail yard died while checking the seals on boxcars for signs of tampering. ${ }^{153} \mathrm{He}$ was aware there would be no warnings or lights when the train moved at night when the incident occurred, and he had been working in the yard for years. ${ }^{154} \mathrm{~A}$ train backing along a track hit him as he inspected another train slowly passing on a parallel track. ${ }^{155}$ When the trains passed each other, he would have had about $3 \frac{1}{2}$ feet of free room to stand between the trains. ${ }^{156}$ The backing train had a bell and the rear brakeman did not have a lantern despite company rules. ${ }^{157}$

The district court granted a directed verdict for defendant and held there was no evidence of neglect and insufficient proof of causation. ${ }^{158}$ The Fourth Circuit affirmed, finding no evidence of employer neglect because the railroad did not owe decedent a duty of care. ${ }^{159}$ The court additionally held decedent had assumed the risks inherent in his employment. ${ }^{160}$ The court reasoned assumption of the risk remained a defense when there was no evidence of employer neglect. ${ }^{161}$

recover, since the employer was not negligent. Id. at 71 (emphasis added).

150. "Once the negligence of the carrier is established, it cannot be relieved of liability by pleading that the employee "assumed the risk." Tiller, 318 U.S. at 71.

151.

The basis of an action under the Act remains the carrier's negligence. The carrier is not to be relieved from the consequences of its negligence by any claim that the employee "assumed the risk" of its negligence. But neither is the carrier to be charged with those injuries which result from the "usual risks" incident to employment on railroads - risks which cannot be eliminated through the carrier's exercise of reasonable care. Id. at 72 .

152. Id. at $55-56$.

153. $I d$.

154. Id.

155. Tiller, 318 U.S. at $55-56$.

156. $I d$.

157. Id. at 56 .

158. Id.

159. $I d$.

160. Id.

161. Tiller, 318 U.S. at 71. 
The Supreme Court in Tiller reversed and held the questions of possible employee and employer negligence should have been submitted to the jury. ${ }^{162}$ Though the Primary Duty Rule was not at issue in the case, the Court observed that prior cases, including Caldine and Davis, represented attempts to discern the distinction between contributory negligence and assumption of the risk. ${ }^{163}$ The Court concluded that Congress "swept into discard" the maze of rules established to differentiate between assumption of the risk and contributory negligence when Congress abolished assumption of the risk as a defense in 1939. ${ }^{164}$ The Court said assumption of the risk is abolished in all its forms. ${ }^{165}$

As will be seen below, the Fifth Circuit, in particular, has seized upon the "swept into discard" language as an indication by the Court that the Primary Duty Rule had been abolished in 1939 when Congress negated the assumption of the risk defense. However, a close reading of the Tiller decision reveals the Court did not actually sweep the Rule into discard, and in fact, the Rule was not at issue in Tiller.

Indeed, the history of the Rule, and Walker itself, decided nine years after Tiller, reveal the Rule does not rest on assumption of the risk as the underlying theory. As said in Walker, the Primary Duty Rule is based on a violation of an employee's conscientiously-assumed duty to his employer, whereas contributory negligence is based upon an employee's violation of a duty to the wrongdoer imposed by law. Assumption of the risk is a defense that an employee proceeded into a situation made dangerous by an employer's neglect. Congress abolished this latter defense in 1939. Therefore, the Rule remained in place after Tiller.

162. Id. at 68

163. Id. at $63-64$.

164. Id. at 64 .

165.

We find it unnecessary to consider whether there is any merit in such a conceptual distinction between aspects of assumption of risk which seem functionally so identical, and hence we need not pause over the cases cited by the court below, all decided before the 1939 amendment, which treat assumption of risk sometimes as a defense to negligence, sometimes as the equivalent of nonnegligence. We hold that every vestige of the doctrine of assumption of risk was obliterated from the law by the 1939 amendment, and that Congress, by abolishing the defense of assumption of risk in that statute, did not mean to leave open the identical defense for the master by changing its name to "non-negligence."

Id. at $58-59$. 


\section{Post Tiller (1943) And Pre Walker (1952)}

In Anderson, the estate of an engineer sued for damages caused by his death in a train collision. ${ }^{166}$ The engineer had failed to blow the train's horn as he approached a siding and crossing. ${ }^{167}$ The conductor, an employee of higher rank than the engineer, failed to stop the train when he did not hear the engineer's whistle. ${ }^{168}$ The conductor's failure at least amounted to neglect. ${ }^{169}$ Both men violated written company rules applicable in the situation. ${ }^{170}$ Since the engineer's neglect was not the sole proximate cause of the engineer's injury, he was permitted to recover for the portion of fault assigned to the owner. ${ }^{171}$ The court distinguished the federal primary duty cases. ${ }^{172}$ The court reasoned that since there was concurrent employer and employee fault, the jury should apportion damages. ${ }^{173}$ The Alabama court did not cite Tiller, and characterized the Primary Duty cases as holding the defense is available when the employee's violation of the duty is the sole and proximate cause of his injuries rather than fault shared between the employee and his supervisor. ${ }^{174}$ The court held that in a case of concurrent employer and employee fault, comparative negligence governs. ${ }^{175}$

In 1947, in Keith, a plaintiff engineer admitted during trial he was negligent in pulling his train out of a siding contrary to written company

166. Atl. Coast Line R.R. v. Anderson, 38 S.E.2d 610 (Ga. 1946).

167. Id. at 611 .

168. Id.

169. $I d$.

170. Id.

171. $I d$. at 616

172. Anderson, 38 S.E.2d at 614.

173. $I d$. (" $[\mathrm{B}]$ ut here, where concurring acts of negligence contributing to the collision are alleged, the recovery, if any, as determined by a jury, must be diminished in proportion to the amount of negligence attributable to the engineer.").

174. Id. at 616 ("All the cases cited recognize that an employee is barred from recovery only when it is shown that the sole and proximate cause of the accident was the employee's own negligence; and in none of those cases was there a failure by a superior to perform a positive duty, which if performed would have prevented the accident.").

175.

Under the state of facts alleged, we think that it makes no difference as to which negligent act was the closer to the collision in point of time. The negligence of both parties flowed toward, and tended to create, the ultimate result. If it might be said that the railroad's negligence was the more remote and the negligence of the engineer was intervening, still the negligence of the railroad was such that it could reasonably have been anticipated and apprehended that it would result in the collision; and that negligence cannot be disregarded. As stated in the Hadley case, supra, "We must look at the situation as a practical unit rather than inquire into a purely logical priority."

Id. at 617 (quoting Union Pac. R.R. v. Hadley, 246 U.S. 330, 333 (1918)). 
orders. ${ }^{176}$ He claimed, however, his superior, the conductor, was negligent in allowing the plaintiff engineer to proceed. ${ }^{177}$ The conductor claimed he never saw a copy of the written orders about the siding, but the company conceded the conductor had a general duty to ensure the train proceeded safely. ${ }^{178}$

Citing Davis, the trial court held that the employer was not negligent for failing to stop a co-employee, there the engineer, from acting as he ought not to act. ${ }^{179}$ The Appellate Court, citing Tiller, said the 1939 amendments "did away with the primary duty rule." and overruled Caldine and Davis. ${ }^{180}$ The court said the Primary Duty Rule was a "phase" of assumption of the risk rejected by the 1939 amendments. ${ }^{181}$

The Keith court remanded the case for a new jury trial and a comparative fault analysis. ${ }^{182}$ On remand, if the jury were to conclude the engineer was solely at fault he could not recover. However, if the conductor, and therefore the employer, were negligent and that negligence resulted in whole or in part in the injury, plaintiff could recover for the employer's share of fault. ${ }^{183}$

In Mangum (1948), the Supreme Court of Alabama cited Tiller, Keith, Caldine and Davis, but and did not opine whether the Primary Duty Rule had been affected by Tiller. ${ }^{184}$ Instead, the court held the Rule not applicable to the facts of the case. ${ }^{185}$ The Court found it dispositive that the plaintiff engineer in Mangum had forgotten his orders rather than disobeyed them. ${ }^{186}$ The court concluded the concurrent fault between employer and employee ${ }^{187}$ was equivalent to that in Keith, so the plaintiff was not precluded from recovery and fault would be apportioned. ${ }^{188}$

176. Keith v. Wheeling \& Lake Erie Ry., 160 F.2d 654, 656 (6th Cir. 1947).

177. Id. at 655 .

178. Id. at 655-56.

179. Id. at $656-57$.

180. Id. at 657 .

181. Id.

182. Keith, 160 F.2d at $657-58$.

183. Id. at 657.

184. Atl. Coast Line R.R. v. Mangum, 34 So. 2d 848, 856 (Ala. 1948).

185. Id.

186. Id.

187.

This [forgetfulness] may have been negligent, but it was not such a conscious disobedience to orders as to make him take all the risk, and relieve the company from responsibility for the concurring negligence of the conductor and other employees whose duty it was to remind him upon being Id. apprised of his forgetfulness.

188. Id. at $856-57$. 
WALKER (1952)

Judge Hand wrote the decision in Walker citing the above cases and in the context of the Rule as it had developed to that time. Therefore, the rank of the employee at issue was not dispositive, and fault by an employer in creating a condition at issue did not negate application of the Rule. The holding in Walker reiterates these aspects of the Rule as it existed in 1952.

Moreover, the Second Circuit's Primary Duty holding came after the 1939 amendments to FELA, and after Tiller and Keith. As said above, Walker differentiated among a duty owed to one's self, a momentary lapse, and a violation of an employment duty. ${ }^{189}$ The court did not base its holding on an assumption of the risk or similar analysis "swept into discard" by Tiller. ${ }^{190}$ Moreover, since a momentary inattention will not preclude recovery under the Rule, the court did not consider the case under negligence principles. Rather, the question, under Walker, was whether plaintiff violated a duty of employment, and whether that violation was the proximate cause of the injury that was the subject-matter of the complaint. ${ }^{191}$ It was immaterial whether plaintiff's duty was to remedy a condition caused by employer fault.

189.

It has been the custom to speak of contributory negligence as a failure by the injured party to discharge a duty owed towards the wrongdoer; and, although it seems anomalous to think of the injured party as being under a duty not to expose himself to the chance that the wrongdoer may himself be delinquent, it makes no practical difference whether one adopts that form of words, or says that duty of the wrongdoer does not extend to, or is modified in its scope in the case of, those who do not look out for themselves. We shall therefore accept the conventional rubric and think of contributory negligence as the breach of a duty to the wrongdoer. The important thing in situations like that at bar is to distinguish between such a duty, which the law imposes upon the injured person, regardless of any conscious assumption of a duty towards the wrongdoer, and a duty which the injured person has consciously assumed as a term of his employment. By "contributory negligence" which results in no more than reducing the amount of an employee's recovery, the Act means the first; the second is a bar to any recovery. This the Supreme Court has decided in a number of cases beginning in 1916 with Great Northern Railway Company v. Wiles, 240 U.S. 444, 36 S. Ct. 406, 60 L. Ed. 732; and it indicated no retreat from the doctrine in Rocco v. Lehigh Valley R.R. Co., 288 U.S. 275,53 S. Ct. 343, 77 L. Ed. 743 , although there it held that the plaintiff had not in fact violated any duty that he had assumed to his employer. The courts of appeal, ourselves included, have applied it in several cases. The theory apparently is that a momentary inattention to one's own safety — the kind of thing of which we are all guilty every day — should not be treated as so serious a fault as the breach of a duty assumed by the employee for the protection of others, although incidentally it is for his own benefit too.

Walker v. Lykes Bros., 193 F.2d 772, 773-74 (2d Cir. 1952).

190. Id.

191. Id. 
Implicit in Walker and its precedents are other elements within the Rule: the seafarer must have been able safely to perform his duty for the Rule to apply. However, it is also entirely possible a seafarer tried and failed to remedy an unseaworthy condition, but still performed his employment duty.

\section{Development of the Rule After Walker (1952)}

In 1953, the Third Circuit in Gill, though it did not mention the Rule, found an employee could not recover for his injuries because there was no evidence the employer's negligence, if any, played a part in the employee's injuries. ${ }^{192}$ In that FELA case, a train worker sued his employer for debilitating head injuries caused when he stood up in an unlit boxcar and hit his head on the bottom of a shelf. ${ }^{193}$ He had never worked in the boxcar prior to that incident, he had been ordered to wear safety goggles (which presumably limited his vision), and the company was on notice that plaintiff may be at risk under the shelves because he had a prior knee injury that required him to crawl on the floor while working. ${ }^{194}$ The Court reversed the judgment for the plaintiff since, even if he proved employer neglect, he failed to prove proximate causation as a matter of law. ${ }^{195}$ His only allegation was the employer was negligent for sending him in the boxcar at all. Even if this were negligence, it was too remote for plaintiff to recover. ${ }^{196}$ The Court reiterated there must be employer fault for plaintiff to recover. ${ }^{197}$

In the context of the present discussion, Gill reinforces prior holdings that an employer will be held liable only for neglect that is a proximate cause of the injury at issue. If a violation of employment duty is the proximate cause of the injury, the Primary Duty Rule applies and the plaintiff is precluded from recovery.

192. Gill v. Pa. Rail Co., 201 F.2d 718 (3d Cir. 1953).

193. Id. at $719-20$.

194. $I d$.

195. "In the instant case, even assuming that the defendant was negligent, there was no causal connection between its negligence and the injury to the plaintiff. We are of the opinion that as a matter of law the case should not have been submitted to the jury." Id. at 721.

196. $I d$.

197. "The Act does not make the employer the insurer of the safety of his employees while they are on duty. The basis of his liability of [sic] his negligence, not the fact that injuries occur. And that negligence must be 'in whole or in part' the cause of the injury." Id. at 720 (citations omitted) (internal quotation marks omitted). 
In 1954, the Fifth Circuit in Johnson declined to extend the Primary Duty Rule to the facts of the case. ${ }^{198}$ The court interpreted Tiller to indicate the Primary Duty Rule had been discarded along with the assumption of the risk defense. ${ }^{199}$

In Johnson, a brakeman sued after suffering an injury in a train collision. Several crewmembers of both trains had violated company rules and also had been negligent. ${ }^{200}$ The jury had awarded plaintiff a verdict after the trial court refused to instruct the jury under defendant's version of the Primary Duty Rule. ${ }^{201}$ The Fifth Circuit affirmed the jury verdict for plaintiff based on a charge that would have barred plaintiff's claim if his negligence was the sole cause of plaintiff's injury. ${ }^{202}$ The court implied that the rank of the plaintiff influenced the result in a Primary Duty Case after Tiller. ${ }^{203}$

Because the jury found defendant's neglect was the sole cause of the incident, there was no discussion of comparative fault. Indeed, the Primary Duty Rule did not apply on the facts, since any violation of duty was not the proximate cause of the injury.

In Dixon, ${ }^{204}$ the Second Circuit, including Judge Hand and Judge Swan from the majority in Walker, ${ }^{205}$ addressed a case in which a chief mate fell from a ladder in a hold. Stevedores had broken the ladder and shore-side

198. La. \& Ark. Ry. Co. v. Johnson, 214 F.2d 290 (5th Cir. 1954).

199. Id. at 292

200. Id. at 291 .

201. Defendant's proposed instruction said:

Where a trainman has a personal duty to perform under the operating rules of the defendant railroad and fails in that duty, as a result of which he is injured, he is not entitled to recover under the Federal Employer's Liability Act, notwithstanding the fact that it was also the duty of other members of the crew to watch for an approaching train with which his train collided, and that their negligence may have contributed in a proximate way to the injury of the plaintiff.

Id. at 291-92 (citing Caldine, Youngblood and Davis) (emphasis added).

202.

We hold, therefore, that there was no error on the part of the district court in refusing to give the appellant's requested charge, nor in the part of its oral charge on the same subject; but that, to the contrary, the court probably charged the jury more favorably to the appellant than it was entitled in submitting to the jury the issue of whether the appellee's negligence was the sole proximate cause of the accident.

Id. at 292 .

203. "Since that decision [Tiller], in cases arising under the Federal Employer's Liability Act, even the engineer has been held not barred by the "primary duty rule." Id. at 292 (citing Anderson, Keith and Mangum).

204. Dixon v. United States, 219 F.2d 10 (2d Cir. 1955).

205. "Dixon, incidentally, was argued and decided while both Judge Learned Hand and Judge Swan were still on the court as Retired Circuit Judges." Reinhart v. United States, 457 F.2d 151, 152 n.4 (9th Cir. 1972). 
contractors had been engaged to repair it. The chief mate descended the ladder without incident, though he could have gone another route, and fell from broken rungs while ascending the ladder. ${ }^{206}$ The rungs, which broke and caused the fall, were not those under repair. ${ }^{207}$

The district court rejected the argument that the mate violated the master's order to check the ladder had been repaired, and that violation of orders caused the injury. ${ }^{208}$ The court found that the chief mate was not contributorily negligent. ${ }^{209}$ The Second Circuit remanded the case for a fact finder to determine the cause of the ladder's failure. ${ }^{210}$

The Dixon court took the opportunity to explain its holding in Walker three years earlier, since defendant argued plaintiff violated his Primary Duty and caused his injury. ${ }^{211}$ The court explicitly stated the Rule is not based on assumption of the risk or contributory negligence. ${ }^{212}$ Instead, the Rule pertains to a breach of a duty created by the employer-employee relationship, as opposed to a breach of a duty to all those foreseeably harmed. ${ }^{213}$ When an employee breaches a duty owed to the employer based on their relationship, he or she is subject to reprimand or discipline, which has the effect of offsetting the employee's personal injury claim against the employer. ${ }^{214}$ The court did not cite Tiller.

This reasoning comports with a theory behind the Rule, that an employer can only remedy unseaworthy conditions through the acts of its employees, so

206. Dixon, 219 F.2d at 11-12.

207. Id.

208. $I d$.

209. "While it is true that Dixon was not as cautious as he might have been, we are unable to say he was unreasonably incautious, so as to justify overturning the lower Court's finding that he was not contributorily negligent." $I d$. at 17.

210. Id. at 13 .

211. Id. at $16-17$.

212. Dixon, 219 F.2d at $16-17$.

213.

Cases such as [Walker]; [Wiles], and other cases of the same tenor which the appellant cites, are in no way inconsistent with the rule that assumption of risk is not a defense or comparable to the situation before us. Those cases are only instances of the firmly established rule that an employee may not recover against his employer for injuries occasioned by his own neglect of some independent duty arising out of the employer-employee relationship. Their result turns really not upon any question of "proximate cause," "assumption of risk" of "contributory negligence," but rather upon the employer's independent right to recover against the employee for the nonperformance of a duty resulting in damage to the employer, which in effect offsets the employee's right to recover against the employer for failure to provide a safe place to work. Such cases are quite inapposite here. Dixon was not guilty of any breach of duty to his employer.

Id. (emphasis added).

214. $I d$. 
those employees cannot recover for an injury occasioned by a violation of duty to remedy the condition. Otherwise, an owner would be an insurer of an accident-free ship, which is not consistent with the general maritime law.

The First Circuit in Boat Dagny, Inc. v. Todd, discussed a suit by the master of a ship for injuries occasioned by his violation of the Primary Duty Rule. ${ }^{215}$ In that case, Todd, the captain of defendant's fishing vessel, fell on a slippery, unlit deck at night. ${ }^{216}$ Prior to the injury, he had not checked if there was a spare part for the damaged part that had doused the lights, did not ask for instructions from the port engineer by radio, though it was standard procedure, and did not use a flashlight when traversing the deck. ${ }^{217}$ The port engineer later testified that the parts were operable, but out of adjustment. ${ }^{218}$

The master admitted it was his duty, through the ship's engineer, to see to it the engines were in adequate operating condition, and that the two men had checked the equipment before the beginning of the voyage. ${ }^{219}$ They found the lights were inoperable but failed to fix them before proceeding. The master did not check for spare parts before the voyage.

The district court found that the master was contributorily negligent and the First Circuit affirmed. The court implied that a master's failure to supervise crew was comparative fault resulting in a diminution of recovery, rather than a bar to recovery under the Primary Duty Rule.

The court found that it was the engineer's primary duty to maintain the lights, not the captain's. ${ }^{220}$ Therefore, application of the Rule to the captain was a strain. The court, citing Tiller, went on to question the Walker holding as invalidly based on an assumption of the risk, so the case at issue was considered as comparative fault between the master and his employer. ${ }^{221}$

215. Boat Dagny, Inc. v. Todd, 224 F.2d 208 (1st Cir. 1955).

216. $I d$.

217. $I d$.

218. $I d$.

219. Id. at 209.

220.

In the first place, the jury would have been warranted in finding on the evidence that the ship's engineer, who was primarily responsible for the proper functioning of the engines, was negligent in not discovering the true cause of the power failure and in not promptly restoring the power for the deck lights by making the necessary adjustment in the tension of the brush springs in the generator.

Id. at 210

221.

It is true that the plaintiff in the due performance of his supervisory responsibilities as master might perhaps have been able to see to it that the engineer got the electric power restored. But if so, his failure to do this was but a species of contributory fault on the plaintiff's part which would go only in diminution of damages instead of being a complete bar to the action. Judge Hand does indicate, 
Todd recognized that a seafarer's duty depends on his rank, and differentiated between supervisory and personal duties. In that case, because it was unclear if the master had violated his primary duty to supervise the engineer in the circumstance at issue, the court correctly did not apply the Rule.

In Mason, the Fourth Circuit did not bar a captain's suit under the Primary Duty Rule. ${ }^{222}$ The captain in that case was, in fact, a non-licensed able-bodied seaman ("A/B") temporarily acting as captain of a tug towing an oil barge. ${ }^{223}$ The injury occurred when he slipped on oil that had been present on the barge since he started work. ${ }^{224}$ The owner claimed he failed in his duty as captain to observe and remedy the oil on the barge when he started his tour. ${ }^{225}$ The owner also claimed that oil on the deck was normal for the type of operations at issue and resulted from priming the oil pumps in the usual manner. ${ }^{226}$ Plaintiff countered that the owner violated U.S. Coast Guard regulations by not having a licensed officer on board and not employing a tankerman whose duties included priming the pumps and cleaning the oil. ${ }^{227}$

The District Court, citing Walker, found that Mason, as acting captain, had actual notice of the oil on the deck and failed in his duties as captain to remedy the problem himself, or order a crewmember to do it. ${ }^{228}$ The Fourth Circuit found the tug did not have a certified tankerman for discharging cargo as required under the Code of Federal Regulations, and distinguished the facts from those in Walker and Todd. ${ }^{229}$ Specifically, the court said Mason, unlike the captain in Walker, was an unlicensed A/B temporarily assigned to work as a captain, and he did not disregard his duty by ignoring the situation over a

in [Walker], supra, that where the master of a ship contributes to his own injury by reason of a breach of his supervisory duties owed to his employer, this is not the type of "contributory negligence" which results under the Act in a mere diminution of the amount of recovery, but rather is a breach of duty to the shipowner which bars the master's recovery "absolutely." For an earlier discussion by Judge Hand of the Supreme Court decisions from which this supposed distinction was derived, see [Van Derveer].

We cannot find in the Act any suggestion that the Congress had in mind this refinement between the two species of contributory fault.

Todd, 244 F.2d at 210-11.

222. Mason v. Lynch Bros., 228 F.2d 709 (4th Cir. 1956).

223. Id. at 710-11.

224. Id.

225. $I d$.

226. Id.

227. Id.

228. Mason, 228 F.2d at $710-11$.

229. Id. at 712 . 
length of time. ${ }^{230}$ The court similarly distinguished Todd and noted the court there reduced the master's recovery as a result of his violation of the Rule, and did not entirely preclude him from recovery. ${ }^{231}$

In short, the court found that the plaintiff in Mason was not a qualified captain with the primary duties incident to that position; he was an A/B unfit to be elevated to captain. Moreover because the company was at fault for employing an unlicensed A/B as a captain, plaintiff would not be held to a captain's duties. Thus, in Mason, as in Todd, the seafarer did not violate his primary duty.

In Rogers, the Supreme Court addressed a suit by a railroad laborer assigned to burn weeds off the track. ${ }^{232} \mathrm{He}$ followed his employer's instructions and stepped back as an oncoming train passed. ${ }^{233}$ However, as he stepped backwards, the passing train fanned the flames and he stepped again quickly backwards and fell into a culvert. ${ }^{234}$

The jury found for plaintiff and the Supreme Court of Missouri reversed, finding plaintiff's negligence was the sole cause of his injuries, and that it was a failure in his primary duty that caused the incident. ${ }^{235}$ The Supreme Court upheld the jury verdict. ${ }^{236}$

The Court said the facts supported the jury's finding that plaintiff's negligence was the sole cause of the incident. ${ }^{237}$ The Court also found there was no evidence that plaintiff violated his duties prior to his accident. ${ }^{238}$ The Court said that if the laborer had been partially at fault, his damages would have been diminished in proportion. ${ }^{239}$ The Court cited Tiller and confirmed that assumption of the risk is no longer a valid defense. ${ }^{240}$

230. $I d$.

231. Id. at $711-12$.

232. Rogers v. Mo. Pac. R.R., 352 U.S. 500 (1957).

233. $I d$.

234. $I d$.

235. Id. at 501.

236. Id. at 511 .

237. Rogers, 352 U.S. at 504-05.

238. $I d$.

239. Id. at 507 n.12 (quoting 45 U.S.C. § 53) ("[T]he fact that the employee may have been guilty of contributory negligence shall not bar a recovery, but the damages shall be diminished by the jury in proportion to the amount of negligence attributable to such employee: Provided, [sic] That no such employee who may be injured or killed shall be held to have been guilty of contributory negligence in any case where the violation by such common carrier of any statute enacted for the safety of employees contributed to the injury or death of such employee.").

240.

The law [FELA] was enacted because the Congress was dissatisfied with the common-law duty of the master to his servant. The statute supplants that duty with the far more drastic duty of paying 
Consequently, Rogers is consistent with the Rule. Since the plaintiff did not violate his primary duty, his suit was not barred under the Primary Duty Rule.

The court in Spero addressed a suit by a third engineer who fell into a hole usually covered by a metal plate in the engine room. ${ }^{241}$ The floor was greasy and plaintiff knew of the condition of the floor, and the absence of the plate, during ship maintenance at the time of the incident. ${ }^{242}$ The court found plaintiff $20 \%$ at fault and reduced his recovery by that portion. The court rejected the application of the Primary Duty Rule in this case. ${ }^{243}$ Simply put, it was not the third engineer's primary duty to maintain the flooring and wipe up the grease.

In a case similar to Walker, the Western District of Pennsylvania, in Elliott, applied the Primary Duty Rule to a suit by a master of vessel after he slipped and fell on a "runner rug" on a waxed linoleum floor. ${ }^{244}$ Presumably, plaintiff's claim was that the floor was slippery because a chambermaid had left excessive wax on the floor ${ }^{245}$ However, the court found no evidence the floor was excessively waxed. ${ }^{246}$ Moreover, the court recognized that the matter of whether to wax the floor was exclusively left to the various masters on the vessel. ${ }^{247}$ Plaintiff said he verbally gave orders to the chambermaid not to wax

damages for injury or death at work due in whole or in part to the employer's negligence. The employer is stripped of his common-law defenses and for practical purposes the inquiry in these cases today rarely presents more than the single question whether negligence of the employer played any part, however small, in the injury or death which is the subject of the suit.

Id. at $507-08$

241. Spero v. Steamship The Argodon, 150 F. Supp. 1 (E.D. Va. 1957).

242. Id.

243.

Respondents urge that such contributory negligence of libellant is sufficient to bar his right of recovery under the doctrine of [Walker]. In [Dagny], the reasoning in Walker, supra, is rather sharply criticized wherein the court refused to attach different consequences to "the two species of contributory fault." This Circuit has declined to choose which course to pursue as between the First and Second Circuits, but has suggested that Walker would only be applicable in any event to a master of an ocean going vessel. [Mason]. Clearly the doctrine cannot be extended to a Third Engineer not primarily charged with the duty of keeping oily substances from the engine room floor. Id. at 3 .

244. Elliott v. Jones \& Laughlin Steel Corp., 166 F. Supp. 731 (W.D. Pa. 1957).

245. Id.

246. Id. at $731-32$.

247. Id. 
the floors when he was on board. ${ }^{248} \mathrm{He}$ claims he also posted the order. ${ }^{249}$ However, he did not follow up to ensure the order had been carried out. ${ }^{250}$

The court cited Walker and Todd and held that the captain's failure to ensure his orders were carried out was not contributory negligence, but instead, was a violation of his primary duty that barred his recovery. ${ }^{251}$ Because the condition of the floors was entirely under his authority, and his primary role was supervisory, ${ }^{252}$ the court dismissed his suit under the Primary Duty Rule. ${ }^{253}$ The court reiterated the Rule is not a corollary of the assumption of the risk defense. ${ }^{254}$

In Ferguson, arguably a case suited for the Primary Duty Rule, the Rule was not argued or mentioned. ${ }^{255}$ There, a second baker lost two fingers while chipping frozen ice cream with a butcher knife. ${ }^{256}$ His duties were to scoop ice cream when waiters on the passenger vessel gave him food orders. ${ }^{257}$ Prior to the accident, another crewmember had neglected to transfer the five gallon jug of ice cream from the deep freezer so it could thaw prior to the meal. ${ }^{258}$

Plaintiff had used an ice chipper to loosen ice cream on other ships but the only device within reach of his station was a butcher knife. ${ }^{259}$ The scooper

248. $I d$.

249. Id.

250. Elliott, 166 F. Supp. at 731-32.

251.

If there was fault on the part of anyone, the fault was plaintiff's for not insisting that the chambermaid comply with his directions. It is not a case of contributory negligence, nor is the conclusion reached here, based upon any assumption of risk on the part of the plaintiff. As between the plaintiff and the owner defendant, the act of the chambermaid is the act of the plaintiff, not that of the owner defendant. Plaintiff, as master, had absolute authority on the issue presented, but in this case not event the chambermaid was shown to have been negligent under the facts presented. Id. at 732 .

252 .

Thus, boiled down, the case is simply one wherein the master is complaining because the chambermaid on the vessel, no doubt the person of least authority, failed to carry out the orders of the plaintiff, who was in command, as to the chambermaid's routine in keeping the vessel clean. This was a matter which the defendant left solely to its vessel captains. What was said by the court in [Patton-Tully] at page 342, applies; [a]lso [Walker, at page 772].

Id. at 732 .

253. Id.

254. Id.

255. Ferguson v. Moore-McCormack Lines, Inc., 352 U.S. 521 (1957).

256. Id. at 522 .

257. Id.

258. Id.

259. Id. 
"was totally inadequate" for the job. ${ }^{260}$ While stabbing the ice cream with the knife, his hand slipped down the blade and he suffered cuts and lost fingers. ${ }^{261}$

The baker sued for Jones Act negligence and the jury awarded him damages. ${ }^{262}$ The appellate court reversed and ordered a directed verdict because it was not reasonably foreseeable that a seafarer would use a knife to scoop ice cream. ${ }^{263}$ The Supreme Court reversed the appellate court since there was sufficient evidence for the jury to find the employer negligent, and that the negligence played a part in the incident. ${ }^{264}$

Had defendant argued the Primary Duty Rule, the defendant still may have lost, as discussed below, since the Court left open whether it was safe for plaintiff to perform his duty in those conditions, and with the equipment, provided. ${ }^{265}$

The Third Circuit in Donovan, another case silent on the Primary Duty Rule, held that an ordinary seaman was precluded from recovery after he negligently loosened a boom that later fell onto his head. ${ }^{266}$ The boatswain had ordered plaintiff to top the boom at issue and plaintiff mistakenly loosened the lines attached to the boom. ${ }^{267}$ On appeal, he argued the boom was unseaworthy so he should recover, even though his negligence caused the unseaworthy condition. ${ }^{268}$ The court held his neglect offset the unseaworthy condition of the boom, so he could not recover. ${ }^{269}$ As an ordinary seaman, Donovan was one of the lowest-ranking members of the crew, and the boatswain was his superior.

Again, the Rule arguably could have applied to this case. However, since plaintiff appeared to have been negligent rather than purposely in violation of his duties, the court correctly did not apply the Rule.

260. Ferguson, 352 U.S. at 522.

261. Id.

262. $I d$.

263. $I d$.

264. Id. at 522-24.

265. "We conclude that there was sufficient evidence to take to the jury the question whether respondent was negligent in failing to furnish petitioner with an adequate tool with which to perform his task." Id. at 522.

266. Donovan v. Esso Shipping Co., 259 F.2d 65 (3d Cir. 1958).

267. "Taken together, all of the evidence points to one inevitable conclusion: the injuries plaintiff sustained were the result of his own negligence." Id. at 67 .

268. Id.

269. "If the injury is caused exclusively by the seaman's negligence, there can be no recovery at all. It is therefore a hollow thing to say that a seaman has a cause of action for a condition created solely by him, but that he cannot recover damages." Id. at 67. 
In Dunbar, decided in 1960, the Second Circuit questioned the durability of the Primary Duty Rule. ${ }^{270}$ In that case, the sole deckhand of a derrick drowned as a tug towed the derrick. ${ }^{271}$ The jury found for decedent but assigned him $20 \%$ fault. ${ }^{272}$ Since the jury was not given special interrogatories to answer, defendant claimed the jury's finding of neglect must have been based on the claim defendant negligently caused the derrick to leak and become unbalanced. ${ }^{273}$ Since caulking leaks and manning the pumps was decedent's duty, defendant argued, decedent should have been precluded from recovery under the Primary Duty Rule. ${ }^{274}$ The owner also argued that, as the sole crewmember, decedent was acting as the master of the derrick at the time of the incident; the Second Circuit disagreed. ${ }^{275}$

Judge Hincks found that decedent did not violate his primary duty by falling asleep during his 17 hours on watch when he could have instead manned the pumps. ${ }^{276}$ Hincks also concluded the owner failed to provide an adequate crew. ${ }^{277}$ In short, this judge found the decedent did not fail in his primary duty and his negligence, if any, was not the proximate cause of his death.

Judge Clark and Judge Waterman, however, added the Walker holding was dicta and not binding on a subsequent panel of the court. ${ }^{278}$ These judges added, in dicta, that the Primary Duty Rule was contrary to Congressional intent to overrule the defenses of contributory negligence and assumption of the risk (citing Todd and not Tiller). ${ }^{279}$ Applying the law to the facts in

270. Dunbar v. Henry Du Bois' Sons, 275 F.2d 304 (2d Cir. 1960).

271. Id.

272. $I d$.

273. $I d$.

274. Id. at 305-06.

275. Dunbar, 275 F.2d at 306.

276. Id. at 306.

277. $I d$.

278. Id. at $305-06$.

279. The court stated:

Efforts made by other circuits to distinguish the Walker case have not been particularly successful. The Fourth Circuit has construed Walker as applying only to masters of oceangoing vessels on long voyages. See [Mason]; [Spero]. However, as we have pointed out in [Dixon], the rationale of the Walker doctrine applies generally to a breach of contractual duty by an employee and does not depend upon the rank of the employee or the class of the vessel or the length of the voyage. We regard the Fourth Circuit's interpretation as a courteous method of escaping the consequences of the Walker doctrine without overtly repudiating an opinion of this court. The Sixth Circuit in [Chesapeake \& Ohio Railway], interpreted Walker as precluding recovery only when the breach of the contractual duty the employee owed the employer was "the sole and proximate cause" of the employee's injury. But this Sixth Circuit effort to avoid express repudiation of Walker is as fruitless as that of the Fourth Circuit. If the employee's negligence was the sole and proximate cause of the 
Dunbar, because it is unclear whether plaintiff violated his duties, and if he could perform those duties safely, the Court correctly did not preclude his recovery under the Rule.

In Williams, decided in 1961, the Fourth Circuit decided that a "Sieracki seaman" (a longshoreman extended the unseaworthiness remedy for a relatively short stint in Supreme Court jurisprudence) was not entitled to recover for unseaworthiness since his own conduct was the sole cause of the incident. ${ }^{280}$ Plaintiff had been operating a winch to raise a hatch cover on a vessel, and injured himself when a metal bar struck him during the process. ${ }^{281}$ After a bench trial, the district court dismissed the case since it found the winch mechanism was seaworthy and the sole cause of the incident was plaintiff's negligent operation of the winch mechanism. ${ }^{282}$ The appellate court affirmed, citing Donovan, and rejected the plaintiff's argument that his suit had been improperly barred under the assumption of the risk defense. ${ }^{283}$ This holding is consistent with prior precedent, and did not add conditions to the Rule's application.

In 1966, the Ninth Circuit, in Schneider, ${ }^{284}$ did not extend the Primary Duty Rule to a suit by a third assistant engineer assigned to fix an electrical box. During the repair, he was electrocuted by hidden exposed electrical wires. ${ }^{285}$ In discussing the Rule, the court said it was the first engineer's duty, not the third assistant's, to inspect the wiring in the engine room. ${ }^{286}$ In that

injury, it is of no moment that this negligence constituted a breach of some contractual duty. The Walker case has been hostilely criticized in the law reviews. See 62 Yale L.J. 111; 65 Harv. L. REV. 1238.

Id. at $306 \mathrm{n} .1$.

280. Williams v. S.S. Richard De Larrinaga, 287 F.2d 732 (4th Cir. 1961).

281. Id. at 734 .

282. Williams v. S.S. Richard De Larrinaga, 180 F. Supp. 6 (E.D. Va. 1960). 283.

Having carefully examined the record, we cannot say that the District Court's findings of seaworthiness of the appliance, of the want of negligence on the part of the ship and owner, and its determination of the sole cause of the accident were clearly erroneous. The appliance used by Williams being seaworthy and Williams' own act being the sole cause of his injury, he cannot recover. Donovan v. Esso Shipping Co., 3 Cir., 1958, 259 F.2d 65, 67.

Williams, 287 F.2d at 735.

284. Hudson Waterways Corp. v. Schneider, 365 F.2d 1012 (9th Cir. 1966).

285. Id. at 1013 .

286. The court stated:

Appellant contends that Schneider is barred from any recovery because he breached the "primary duty rule" established by Walker v. Lykes Bros. Steamship Co., Inc., 2 Cir., 193 F.2d 772. This rule provides that "an employee may not recover against his employer for injuries occasioned by his own neglect of some independent duty arising out of the employer-employee relationship. Their result turns . . . upon the employer's independent right to recover against the employee for the non- 
case, the assistant engineer's superior had ordered the assistant to fix the electrical box. However, he could not do so safely because of the latent condition of the box. Consequently, the court correctly found the Rule did not preclude his recovery, though he was unsuccessful in performing his primary duty. ${ }^{287}$

Later in 1961, the Fifth Circuit held the Primary Duty Rule did not govern the facts of Schlichter. ${ }^{288}$ There, the engineer of a small pushboat drowned after trying to urinate over the side while drunk. ${ }^{289}$ Plaintiff was the sole crewmember left aboard the vessel while it was docked for several days at a chemical company. ${ }^{290}$ During that time, the owner charged plaintiff with safeguarding the movable equipment on the vessel from pilferage. ${ }^{291}$ Sometime later, plaintiff locked the doors on the vessel before leaving with some friends to go to engage "in some concentrated drinking." 292

Plaintiff returned and fell overboard while urinating over the side. ${ }^{293}$ The bathroom doors were later found locked. ${ }^{294}$ One of his friends went into the water, presumably to help the plaintiff, while the other friend tried to get a life preserver. ${ }^{295}$ However, the man on the vessel could not find a life preserver because the accommodation doors were locked and both men in the water died. ${ }^{296}$ The court did not apply the Primary Duty Rule to this situation, but affirmed the trial court's directed verdict for defendant. ${ }^{297}$

performance of a duty resulting in damage to the employer, which in effect offsets the employee's right to recover against the employer for failure to provide a safe place to work." Dixon v. United States, 219 F.2d 10 (2d Cir.).

However, here appellant has failed to prove that Schneider, the Third Assistant Engineer, was charged with the primary duty to inspect, repair and maintain the electrical system in question. There is evidence that he had made a routine tour of inspection of the engine room a few hours before the accident, but this does not establish that Schneider had a duty to inspect the inside of the switch box. To hold otherwise would be to bar any engineer on watch from recovery for injury resulting from any dangerous condition in the engine room, no matter how latent that condition might be. Schneider testified in response to questions by the appellant, that it was the duty of the First Engineer, and not Schneider's duty, to inspect the wiring. Id. at 1015-16 (emphasis added)

287. Id.

288. Schlichter v. Port Arthur Towing Co., 288 F.2d 801 (5th Cir. 1961).

289. Id. at $801-03$.

290. $I d$.

291. $I d$.

292. Id. at 802 .

293. Schlichter, 288 F.2d at 801-03.

294. Id.

295. Id.

296. Id.

297. “'Under this statute [the Jones Act] the test of a jury case is simply whether the proofs justify 
The court found there was no evidence defendant's negligence if any, played any part in plaintiff's death: plaintiff locked the doors, there was no proof that if the doors were open a life jacket could have been obtained in time to save him, there was no industry custom about having life jackets available on deck, and plaintiff's duty was to safeguard the ship and therefore, to keep it locked when he was not on board. ${ }^{298}$ The court did not apply the Primary Duty Rule, largely without comment, though the court did say the Rule had been subject to criticism. ${ }^{299}$ Because the court focused on plaintiff's neglect, rather than on violation of duty, the court was correct in its reasoning and holding. However, if the court had determined plaintiff's primary duty was to safeguard the ship, he likely violated that duty and caused his accident, so the Rule could have barred his recovery as well.

Another major case in the evolution of the Rule is the Ninth Circuit's Reinhart decision in $1966 .{ }^{300}$ In that case, a chief mate sued the United States under the Public Vessels Act and Suits in Admiralty Act after he fell through sheathing while walking in the ship's hold to search for rats. ${ }^{301} \mathrm{He}$ had a flashlight but was using it to spot rats instead of looking where he walked. ${ }^{302}$

The Ninth Circuit interpreted Schneider as holding that a subordinate will not be barred from recovery when he is performing his superior's primary

with reason the conclusion that employer negligence played any part, even the slightest, in producing the injury or death for which damages are sought."' Id. at 806-07 (quoting Rogers v. Missouri Pacific Ry. Co., 352 U.S. 500, 506 (1957)).

298.

This is not to make the owner's obligation to the one in charge any less exacting, or somehow to charge that person with the full, not pro rata consequences, of any mistaken judgment as may have been the case in [Walker]. Here on uncontradicted facts there was an ample supply of life jackets. Located where they were, in the galley just a few feet from the scene with more of them stored in the crew's quarters a few feet beyond, they would have been immediately - and hence readily - available had the doors not been locked. As to this claim Schlichter and those suing of proof that he had say - in the absence of proof that he had positive orders overriding his freedom of judgment as to locking the doors - that it was the shipowner's negligence which resulted in these life jackets being unavailable.

In addition to these insuperable obstacles nowhere overcome by any evidence, there is a total lack of any evidence to show that under these unique conditions, availability of life jackets, or ring life buoys, in the galley messroom or elsewhere would have saved Schlichter's life. Of course the standard is now well known and has been variously stated. "Under this statute the test of a jury case is simply whether the proofs justify with reason the conclusion that employer negligence played any Id. part, even the slightest, in producing the injury or death for which damages are sought." [Rogers]

299. Schlichter, 288 F.2d at 805 n.3 (citing Todd, Johnson and Mason).

300. Reinhart v. United States, 457 F.2d 151 (9th Cir. 1972).

301. Id.

302. $I d$. 
duty - a duty that had been delegated. ${ }^{303}$ Moreover, the court in Reinhart observed that Judge Hand, the author in Walker, was still on the Second Circuit when it decided Dixon. ${ }^{304}$ The Reinhart court went on to state that Walker was decided in contemplation of the 1939 amendments that abolished the assumption of the risk defense. ${ }^{305}$ The court indicated that the Primary Duty Rule rests not on contributory negligence nor assumption of the risk. Instead, the Rule reflects the employer's right to recover from the employee for a breach of an independent duty arising from employment. Moreover, the Rule is not based upon a duty of care arising by law or arising from an analysis of reasonable conduct in the circumstances. ${ }^{306}$

The Ninth Circuit noted that an owner will be liable for an unseaworthy vessel, regardless of fault, and independently from an analysis under the Jones Act for negligence. ${ }^{307}$ However, the court, citing Walker, found for the employer since it was plaintiff's duty to maintain the vessel's seaworthiness, specifically, the sheathing at issue. ${ }^{308} \mathrm{He}$ could have provided adequate

303.

Quite correctly and consistently with Walker, we held that the rule of that case did not apply because there was no proof that libelant, as Third Assistant Engineer, had the duty and responsibility to maintain the electrical system, including the switch box, in repair. That was the duty of the First Engineer and Schneider had an absolute right to recover damages mitigated only by what negligence could be ascribed to his own actions. He assumed no duty which barred his recovery, the duty and negligence of the officer primarily responsible could not be delegated to Schneider and the rule of Walker did not apply.

Id. at 155 (emphasis added).

304. Id. at 154 n. 4 .

305. Id. at $154-55$.

306.

Appellant calls our attention to [Dagny], as a case which correctly analyzes [Walker] as simply distinguishing the legal consequences between two types of contributory negligence. All of this, it is argued, has been "swept into discard" by the 1939 amendment of the Federal Employers' Liability Act, and the decision of the Supreme Court in [Tiller] Boat Dagny v. Todd, supra at 211.

We cannot accept such an over-simplified explanation of [Walker]. That case was decided in 1952, long after the Federal Employers' Liability Act amendment and the decision in Tiller. It seems naive to assume that neither Judge Hand nor his associates, Chief Judge Swan and Judge Augustus Hand, were aware of either the statute or the decision.

We do not believe [Walker] stands for a distinction between two types of contributory negligence or assumption of risk. On the contrary, we are more persuaded by Judge Harlan's above-quoted analysis of [Walker] in [Dixon]. [The Rule is based on a violation of duty that permits the employer to recover against the employee.] He correctly points out that the rule of Walker is "in no way inconsistent with the rule that assumption of risk is not a defense...", and that the result in Walker does not turn on any question of assumption of risk or contributory negligence.

Reinhart, 457 F.2d at 154.

307. Id. at 152 .

308. Id. at $152-53$. 
lighting during the ample time between when he should have inspected the hold and when he entered the hold and fell. ${ }^{309}$ Since he violated his positive employment duty to inspect the hold safely and was injured as a result, the Rule precluded his recovery. ${ }^{310}$ His failure to perform his duty was more than a momentary lapse. ${ }^{311}$

Moreover, Reinhart also explained cases such as Williams, Donovan and Schlichter as resulting from a "natural corollary" of the Walker rule, namely, that one cannot recover for unseaworthiness if the injury was caused solely by plaintiff's neglect. ${ }^{312}$

In Sotell, a second assistant engineer with 40 years experience was injured by an explosion in the forced-draft blower. ${ }^{313}$ He had closed the exhaust valve, contrary to proper operating procedure, and caused the explosion. ${ }^{314}$ The district court dismissed his suit after a bench trial. ${ }^{315}$ The appellate court affirmed, citing Dixon and Donovan, since there was enough evidence to support a jury's conclusion that his neglect was the sole cause of the incident. ${ }^{316}$

Since this was a case in which plaintiff had a momentary lapse, instead of a conscious violation of duty, the court correctly decided the case on negligence principles. ${ }^{317}$

Plaintiff in Noack worked as a wiper whose duties included mopping up grease and oil from the decks of the vessel. ${ }^{318}$ Plaintiff hurt his back when he slipped into a deck opening while cleaning bilges in the lower engine room. ${ }^{319}$ $\mathrm{He}$ caused the slippery condition as he carried buckets of bilge slop and

309. Id. at 154 .

310. Reinhart, 457 F.2d at 155.

311.

In Walker, Judge Hand "distinguished between momentary failure to exercise due care, which characterizes contributory negligence, and the failure to perform a positive duty, which the injured party has knowingly and advisedly entered into with his employer. This latter type of failure had proximately caused Walker's own injury, for which he nonetheless sought to recover damages from his employer."

Id. at 153 .

312. Id. at $154 \mathrm{n} .3$.

313. Sotell v. Mar. Overseas Inc., 474 F.2d 794, 795 (2d Cir. 1973).

314. $I d$.

315. Id.

316. Id. at 796 .

317. $I d$.

318. Noack v. American S.S. Co., 491 F.2d 937, 938 (6th Cir. 1974).

319. Id. 
spilled them on the deck plates. He then slipped on the slop he had spilled. ${ }^{320}$ The jury found him fifty percent at fault and the appellate court affirmed. ${ }^{321}$

Defendant, citing Reinhart, claimed plaintiff, as a wiper, had an independent duty to clean up oil and grease and he knew of those conditions before working at the bilge. ${ }^{322}$ The court found plaintiff did not have a general duty to clean decks, but, rather, his duty was to clean after a specific order to do so. ${ }^{323}$ The record did not show he deviated from the usual practice or degree of care. ${ }^{324}$ The jury also found that the injuries were not caused by plaintiff's failure to perform his duties as a wiper. ${ }^{325}$ The deck plates were worn and slippery at the time of the incident, and there was no duty to clean the plates as the seafarers cleaned out the bilges. ${ }^{326}$ Since plaintiff did not violate his primary duty in the circumstance, the court properly did not bar the suit based on the Rule.

Several months later in 1974, the First Circuit in Peymann $^{327}$ recognized the validity of the Primary Duty Rule, ${ }^{328}$ but said it did not govern the circumstances under review. ${ }^{329}$ The district court directed a verdict for defendant on the Jones Act claim and the jury found for defendant on the

320. Id.

321. $I d$.

322. Id. at 941.

323. Noack, 491 F.2d at 941

324. $I d$.

325. $I d$.

326. $I d$.

327. Peymann v. Perini Corp., 507 F.2d 1318 (1st Cir. 1974).

328. "Walker has been read to bar recovery whenever a seaman's injury has been caused in part by the breach of his contractual duty to his employer, thus permitting an employer's action for nonperformance, and creating a set-off." Id. at 1322 .

329. The court said:

We regard this as quite different from Walker, where the master failed to supervise himself, and the fault was his alone. While we criticized some of the court's language, Boat Dagny [Todd] does not contradict a strict reading of Walker that a seaman may not recover where his breach of duty constitutes the sole cause of injury. Our decision merely followed the self-evident proposition that not every breach of duty will assign a seaman full responsibility for his injury. See also Noack, ante, 491 F.2d at 941; Mason v. Lynch Bros. Co., 4 Cir., 1956, 228 F.2d 709, 712; Becker v. Waterman S.S. Corp., 2 Cir., 1950, 179 F.2d 713, 715-16. In the case at bar, as in Walker, the jury might have found it was plaintiff's primary duty to maintain the engine room in a seaworthy condition, and that his conduct in stepping on the rail without first wiping off the oil, placed there by his own conduct, was his sole responsibility.

Id. at 1323 (emphasis added). 
unseaworthiness cause of action. ${ }^{330}$ While the First Circuit noted the issues were similar to those in Walker, the court affirmed on other grounds. ${ }^{331}$

In Peymann, a chief engineer of a tug slipped and fell while perched "like a bird" on an oily railing as he worked in the engine room with an overhead chain and tackle. ${ }^{332}$ He claimed the owner improperly failed to furnish him with a ladder or an assistant. ${ }^{333}$ The jury concluded that he was solely in charge of the operation and solely at fault in failing to maintain the engine room in a seaworthy condition..$^{344}$ Therefore, plaintiff's neglect caused the unseaworthy condition and injury. ${ }^{335}$ Since neglect is independent of the Primary Duty Rule, the court correctly concluded the Rule did not apply to the facts.

In Perry, a wiper fell on stairs he claimed were greasy, but he did not submit any proof there was actually grease on the stairs. ${ }^{336}$ Prior to his fall, he and other seafarers had been assigned to carry buckets of oil down the twenty interior stairs where plaintiff later fell. ${ }^{337}$ The jury found the vessel was seaworthy but the owner was negligent. ${ }^{338}$ On review, the court upheld the seaworthiness verdict and reversed the negligence verdict since it was not supported by the record. ${ }^{339}$

Plaintiff also did not prove the owner knew, or should have known, of grease on the stairs. ${ }^{340}$ Even under the "slight negligence" standard in the Fifth Circuit before Gautreaux, the court found there should have been a directed

330. Id. at 1320 .

331. Id.

332. $I d$.

333. Peymann, 507 F.2d at 1321.

334.

Consequently the complained-of instruction was, both because of other instructions, and in direct terms, applicable only if the jury found that the accident was due solely to the failure of plaintiff, as the one in charge, to have the engineroom seaworthy by obtaining an available ladder or, if it was proper to use the rail, to see that it was free of oil before he stepped on it.

Id. at 1321.

335.

We see little difference in the present case. Plaintiff, in charge of the operation, knew that the cylinder heads dripped oil. He knew, too, that it was his duty to keep the engineroom in a safe condition. Instead of passing a rag over the rail, he proceeded, indifferently, to step on it, and then, unless the court's instruction was correct, would seek to hold the ship even though the jury were to find the fault solely his.

Id. at 1322 .

336. Perry v. Morgan Guar. Trust Co. of N.Y., 528 F.2d 1378 (5th Cir. 1976).

337. Id. at 1379 .

338. Id.

339. $I d$.

340. Id. 
verdict for defendant. ${ }^{341}$ In Perry and similar cases, the Primary Duty Rule could have provided another basis for dismissing the suits. If a seafarer's failure to perform his duty is the proximate cause of his injury, he is precluded from recovering for unseaworthiness or negligence. However, if the seafarer's neglect is the sole cause of his injury, his suit should be dismissed under comparative fault principles.

In Rivers, a captain of a jack-up boat fell into a hole while disembarking the vessel. ${ }^{342}$ The state appellate court affirmed the verdict for plaintiff. Defendants argued the Primary Duty Rule applied since the captain did not maintain a safe berth, did not dock at a safe berth, and did not choose a safe place to walk, each in violation of his duties as captain. ${ }^{343}$ The court rejected the Primary Duty Rule arguments, citing Peymann, Reinhart, and Walker. ${ }^{344}$ The court said these cases held the Rule only applies when a seaman's violation of duty is the sole cause of the injury, ${ }^{345}$ which was not so in the case under consideration.

Interestingly, in each of the cases the Rivers state court distinguished, the seafarer failed in his duty to remedy an unseaworthy condition, so there was not necessarily employer fault in those cases. ${ }^{346}$ Moreover, the court evaluated the Rule and its application in the context that seafarers are wards of the court with a slight duty of care when performing their duties. ${ }^{347}$ This decision was rendered by the state court in Louisiana applying federal admiralty law. ${ }^{348}$

Since the Primary Duty Rule is not a negligence standard, whether a seafarer owes himself "slight" or "ordinary" ${ }^{349}$ care should not implicate the application of the Rule. If the captain in Rivers did violate his duty to find a safe berth or maintain the berth at issue, and his injury resulted from his conscious disregard of such a duty, his suit should have been dismissed under the Rule.

341. "That only the slightest negligence need be shown to uphold the award of damages in such cases does not mean, however, that the seaman may prevail on no evidence at all." Perry, 528 F.2d at 1380.

342. Rivers v. Schlumberger, Well Surveying Corp., 389 So. 2d 807, 809 (La. Ct. App. 3d Cir. 1980).

343. Id. at $809-11$.

344. Id. at 814 .

345. Id.

346. $I d$.

347. "A seaman's duty to protect himself is slight. His duty is to do the work assigned, not to find the safest method to work. Spinks v. Chevron Oil Company, supra. Any negligence of a seaman which causes his injury is subject to the law of comparative negligence." Rivers, 389 So. $2 \mathrm{~d}$ at 816 (citing Spinks v. Chevron Oil Co., 507 F.2d 216, 223 (5th Cir. 1975)).

348. Id. at 817 .

349. Gautreaux v. Scurlock Marine, Inc., 107 F.3d 331, 334 (5th Cir. 1997). 
In Johannessen, the Second Circuit reversed and remanded a trial court's directed verdict for defendant. ${ }^{350}$ The district court had ruled plaintiff's negligence claim was barred by the Primary Duty Rule and the unseaworthiness claim failed because plaintiff did not prove causation. ${ }^{351}$ In that case, the captain of a tanker died while checking a stopped valve as the ship loaded gasoline; the captain, and an $\mathrm{A} / \mathrm{B}$, died of asphyxiation after entering the hold without air masks. ${ }^{352}$

The Second Circuit found the master was negligent because he entered the hold without an air mask in violation of United States Coast Guard regulations. ${ }^{353}$ However, the court added that the jury could also find the coemployees were negligent in the "utter chaos" of their rescue effort, so the employer may have been concurrently negligent. ${ }^{354}$ Therefore, the court held, the case should have been considered by the jury in a comparative fault analysis. ${ }^{355}$ The court found the Primary Duty Rule did not apply because the Rule only precludes a seafarer's claim when his fault is the sole cause of his injury. ${ }^{356}$

The court also said Walker holds the Primary Duty Rule only precludes recovery when the seafarer's negligent violation of a duty is the sole cause of the incident. ${ }^{357}$ The court reasoned the jury could find concurrent negligence by the co-employees, and in the lack of an extra air mask in the vicinity of the hold. ${ }^{358}$ The captain's duties ended once he became unconscious. Thereafter, the shipowner's neglect caused his death.

Here again, the Second Circuit recognized the continued vitality of the Primary Duty Rule, though the court held, in the context of concurrent fault, that the employee's violation of duty must be the only cause of a seafarer's incident. However, the court did so while stating the Rule applies to a "negligent" violation of duty, which does not satisfy Walker's Primary Duty Rule requirement of a violation of a consciously-assumed duty. ${ }^{359}$ In

350. Johannessen v. Gulf Trading \& Transp. Co., 633 F.2d 653, 657 (2d Cir. 1980).

351. Id. at $654-55$.

352. $I d$.

353. $I d$.

354. Id. at 655

355. Id.

356. Johannessen, 633 F.2d at 656.

357. Id. at $656 \mathrm{n} .3$.

358. "We believe that a jury may, but need not, find that the unseaworthy valve was a direct but concurrent cause of Captain Johannessen's death, along with his own negligence, and possibly the negligence of his fellow servants." Id. at 657 n.5.

359. Id. at 656 . 
Johannessen, the court did not find a knowing disregard of duty by anyone involved; therefore, the Rule did not apply and negligence principles governed the case. ${ }^{360}$

In 1981, the Southern District of New York, in Saleeby, ${ }^{361}$ questioned the Primary Duty Rule, though the Rule was not applicable to the facts at issue, which the court viewed in the light most favorable to the plaintiff. ${ }^{362}$

In that case, a chief engineer slipped and fell on ice accumulated on the deck from the stores container ("meat box"). ${ }^{363}$ The meat box had defective heating coils, which caused it to overheat, leak water and cause ice to form on the deck. ${ }^{364}$ The master knew of the problem and notified the home office about the need for spare parts. ${ }^{365}$ The parts did not arrive on the ship even though the ship called at several ports in the time intervening between the master's report and the fall. ${ }^{366}$

The jury found for plaintiff in the unseaworthiness claims, but found plaintiff fifteen percent at fault in the Jones Act negligence claim. ${ }^{367}$ Defendant moved for judgment notwithstanding the verdict, in part, based on the Primary Duty Rule. After viewing the facts in a light most favorable to plaintiff, the court denied defendant's motion as it pertained to liability. ${ }^{368}$

In its opinion, the court did not discuss whether the chief was primarily responsible to repair the meat box and somehow violated that duty. However, it was clear the employer, not the chief, controlled whether the spare part

360. Id.

361. Saleeby v. Kingsway Tankers Inc., 531 F. Supp. 879 (S.D.N.Y. 1981).

362 .

We also disagree with the defendant that plaintiff breached a duty owing to his employer. The 'Walker' doctrine, although to date not overruled, has repeatedly been unavailing to defendants in our Circuit's Court of Appeals. See Johannessen v. Gulf Trading, 633 F.2d 653, 655 n.3 (2d Cir. 1980); Berke v. Lehigh, 435 F.2d 1073 (2d Cir.), cert. denied, 404 U.S. 825, 92 S. Ct. 55, 30 L. Ed. 2d 53 (1970); Dunbar v. DuBois' Sons Co., 275 F.2d 304, 306 (2d Cir.), cert. denied, 364 U.S. 815, 81 S. Ct. 45, 5 L. Ed. 2d 46 (1960); 1B Benedict on Admiralty $\S 25$, n.28 (7th ed. 1980). Id. at 881 .

363. Id. at $880-81$.

364. Id.

365. Id.

366. Saleeby, 531 F. Supp. at $880-81$.

367.

On November 18, 1980 the jury delivered a verdict in favor of the plaintiff for $\$ 1,510,705$ on the two theories of liability submitted to it for determination: unseaworthiness and violation of the Jones Act, 46 U.S.C. $\& 688$. Pursuant to special interrogatories submitted to it, the jury determined that the plaintiff was $15 \%$ contributorily negligent; that of the entire general verdict, past and future medical expenses amounted to $\$ 263,000$.

Id. at 880 .

368. Id. 
necessary for the repair arrived on the ship. The captain ordered the part and the company failed to deliver the part to the ship for installation. Thus, even if it were the chief's duty to repair the box, he did not violate that duty and he was not injured as a result of his violation of that duty.

The Fourth Circuit in 1982 affirmed a judgment for plaintiff who arguably violated his duty to carry out repairs safely. ${ }^{369}$ McCoy, a QMED (Qualified Member of the Engine Department), had two accidents in the engine room. ${ }^{370}$ In the first, he slipped and hurt his shoulder while adding oil to a draft fan that had been leaking large amounts of oil for about a month. ${ }^{371}$ In his second incident, officers ordered McCoy to repair a broken fuel line, which required that he lay in oily bilge water while making the repairs. ${ }^{372}$ An assistant engineer assisted him but did not know where to find a part, so McCoy exited the water to get the part and slipped and hurt his shoulder as he stepped back into the bilge water. ${ }^{373}$

The trial court found both conditions were unseaworthy. ${ }^{374}$ The court held the shipowner liable for the injury caused by the leaky fan, but the court found the sailor could not recover for the injuries from the unseaworthy burst fuel line since he fell as a result of his obligation to cure the unseaworthy condition. ${ }^{375}$ The appellate court affirmed the finding for plaintiff in the leaky fan incident, but reversed the trial court's verdict for defendant in the ruptured fuel line incident. ${ }^{376}$ The court noted a seafarer will not be barred from recovery if his injury resulted from his failure to choose a safer method of performing his work. ${ }^{377}$ The court indicated the seafarer's recovery would have been reduced had the shipowner proved the sailor suffered an injury due to his failure to choose a safe method to work. ${ }^{378}$ His employer, the government, conceded the burst fuel line was unseaworthy, but claimed McCoy was at fault for not safely performing his duties. ${ }^{379}$ The court found no evidence McCoy had a safer alternative when he tried to perform his duties,

369. McCoy v. United States, 689 F.2d 1196 (4th Cir. 1982).

370. Id. at 1197.

371. $I d$.

372. $I d$.

373. Id.

374. McCoy, 689 F.2d at 1197.

375. Id. at 1198.

376. Id. at 1199 .

377. Id. at 1198-99.

378. Id.

379. McCoy, 689 F.2d at 1199. 
so it affirmed, in part, that defendant was liable. ${ }^{380}$ The court also did not find persuasive the argument that plaintiff knowingly worked in the face of a risk. ${ }^{381}$

McCoy solidifies an implied aspect of the Primary Duty Rule, namely, that plaintiff will not be barred from recovery unless he could have safely performed his duty and failed to do so.

In Vest, the captain of a shrimp trawler suffered an injury when the top of a ladder disengaged from the vessel and he fell to the deck. ${ }^{382}$ At trial, the shipowner successfully argued it was not negligent and vessel was seaworthy. ${ }^{383}$ On review, the Eleventh Circuit found the vessel was unseaworthy. ${ }^{384}$ The court also declined to apply the Primary Duty Rule though it was the captain's duty to keep the vessel safe. There was no evidence the Captain knew the ladder was broken, so he did not have a duty to fix it. ${ }^{385}$

380.

We have consistently held that a seaman cannot be faulted for recognizing his job is dangerous and doing it anyway, unless he deliberately spurns a safe alternative provided him. See Sessler v. Allied Towing Corp., 538 F.2d 630 (4th Cir. 1976); Smith v. United States, 336 F.2d 165 (4th Cir. 1964).

The burden of showing that a safe alternative existed, as part of the affirmative comparative negligence defense, rests with the shipowner. See Mason v. Mathiasen Tanker Industries, Inc., 298 F.2d 28, 32 (4th Cir. 1962).

Id. at 1198 .

381.

It is irrelevant that the unseaworthy condition was obvious to McCoy unless it was shown that he spurned safe alternatives. McCoy's duty was to maintain the fans, and he cannot be held to have breached this duty simply by recognizing the job was dangerous.

Id. at 1197 .

382. In re the Complaint of Villers Seafood Co. v. Vest, 813 F.2d 339, 340 (11th Cir. 1987).

383. $I d$.

384. Id. at 343 .

385 .

Nor would Vest's failure to discover and correct the unattached ladder constitute a bar to recovery. Vest did testify that it was his duty to keep the vessel in repair, and some courts have denied recovery under the Walker doctrine which states that a ship's officer whose breach of duty to maintain a safe ship has caused his injury by an unseaworthy ship or appliance may not recover damages for his injuries. However, in each of the cases in which the court has denied recovery the injured officer actually knew of the existence of the unseaworthy condition before the accident. We are unwilling to extend the doctrine to a case in which no misconduct or actual knowledge of the existence of an unseaworthy condition has been proven. The owner's right to have his conditions of employment and instructions obeyed is adequately vindicated in this case by application of mitigation of damages according to the doctrine of comparative negligence.

Id. at $342-43$. 
Plaintiff in Yehia appealed from a jury verdict for defendant. ${ }^{386}$ The jurors had considered a charge that instructed them to find for defendant if plaintiff's injuries resulted solely from a violation of his responsibilities for defendant. ${ }^{387}$ The Sixth Circuit reversed and found there was no evidence plaintiff failed in his duties. ${ }^{388}$ In its decision, the court applied the Primary Duty Rule but held the facts did not warrant plaintiff's suit should be barred by the Rule. ${ }^{389}$ The dissent pointed out the jury also found the vessel was seaworthy, further complicating the instructions on remand. ${ }^{390}$

In that case, plaintiff, a deckhand, suffered two injuries from two separate incidents involving falls in the hold of a bulk cargo carrier. ${ }^{391}$ The floors of the cargo hold were slanted sharply downward to ease the movement of bulk cargo into hoppers, then through a tunnel and onto a conveyor belt for unloading. ${ }^{392}$ During the unloading process, the machinery left grease and oil on the hold floor, which deckhands, such as plaintiff, were assigned to clean using a pressurized hose. ${ }^{393}$ During the first incident, plaintiff fell on grease while hosing the flooring. ${ }^{394} \mathrm{He}$ fell again a few months later while shoveling the cargo in hold. Again, he fell on grease on the slanted flooring. ${ }^{395}$

The court held he did not violate his Primary Duty in either event, so the jury should not have been charged that if they find the vessel unseaworthy, and the sole cause of plaintiff's injury was his failure to perform his duty, he cannot recover. ${ }^{396}$ The court cited the Primary Duty Rule from Peymann and distinguished the facts of that case from the case under consideration, since,

386. Yehia v. Rouge Steel Corp., 898 F.2d 1178, 1179 (6th Cir. 1990).

387. $I d$.

388. Id. at 1185 .

389. Id. at 1184 .

390. Id. at 1185 .

391. Id. at $1197-80$.

392. Yehia, 898 F.2d at $1179-80$.

393. $I d$.

394. $I d$.

395. $I d$.

396.

The rule is not different in this circuit: "A seaman may not be denied recovery because he proceeds in an unsafe area of the ship or uses an unsafe appliance in absence of a showing that there was a safe alternative available to him." Tolar v. Kinsman Marine Transit Co., 618 F.2d 1193, 1195 (6th Cir. 1980).

In the case at bar there was not a shred of evidence that Mr. Yehia had a safe alternative available to him. The district court implicitly recognized as much.

Id. at 1183 . 
in the latter, plaintiff suffered his injury while performing his duties and there was no evidence he had a safer alternative available. ${ }^{397}$

This case furthers the portion of the McCoy holding that indicates a seafarer must be able to perform his duties safely for the Rule to be considered. This aspect of Yehia was central to the reasoning in Walker where the Captain was barred from recovery, in relevant part, because he could have safely performed his duties, but failed to do so.

In Joia, an engineer slipped and fell on oily water in a tug's engine room. ${ }^{398}$ The tug's operator had caused the slippery condition when he mistakenly filled a hydraulic oil tank with water until it overflowed. ${ }^{399}$ Plaintiff saw this condition, reported it to the shipowner and suggested they use a pump. ${ }^{400}$ The owner asked plaintiff to buy and install the pump to lower the level in the oil tank. ${ }^{401}$ Plaintiff bought the pump at a local store, returned to the engine room and fell before he could install the equipment. ${ }^{402}$ The jury found for plaintiff but found him five percent at fault in the incident. ${ }^{403}$ Defendant appealed the denial of its motions for a directed verdict and judgment n.o.v. ${ }^{404}$

On review, the court held the Primary Duty Rule did not apply because plaintiff had not violated his duty. ${ }^{405}$ The court found dispositive that the

397.

The distinctions between that case [Peymann] and this are obvious. There was no showing here that plaintiff Yehia had "the primary duty" - or any duty—to clean up oil from the deck of the cargo hold. Unlike the plaintiff in Peymann, moreover, who did no cleaning at all, plaintiff Yehia was injured in the very act of performing the cleaning operations he had been assigned to perform. There was no showing here that plaintiff Yehia proceeded "unnecessarily" to perform his assigned tasks without first wiping the decks clean. And there was no showing here that plaintiff Yehia abused any "free choice" between a safe method of proceeding and an unsafe method. Mr. Yehia's job was to shovel up the loose cargo and hose out the residue. That was precisely what he was doing, using the tools be (sic) was supposed to be using and standing where he was supposed to be standing.

Id. at 1184 .

398. Joia v. Jo-Ja Service Corp., 817 F.2d 908 (1st Cir. 1987).

399. Id. at $910-11$.

400. $I d$.

401. $I d$.

402. $I d$.

403. Joia, 817 F.2d at $909-10$.

404. Id.

405.

In Peymann, the plaintiff was responsible for creating the condition which caused his injuries, whereas here, a third party over whom Joia had no control created the unseaworthy condition on the engine room deck of F/V NIAGARA FALLS. Joia testified that the maintenance of the engine room was his responsibility. Co-owner Pimental directed him to clean the mess, saying: "If you said this is a big old mess, you go clean it up." Joia responded that he needed to pump out some of the water 
employer had left the specific method of carrying out his duty to plaintiff. Because plaintiff was not given precise instructions, his choice to install the pump before cleaning the floor was not a violation of his duty. ${ }^{406}$

Two months after Joia in 1987, an interesting analysis of the Primary Duty Rule took place in the Maine district court in Snow. There, a crewmember (rank not specified) sued for an injury caused by the lack of a protecting mechanism over the moving belts of an alternator. Plaintiff had been ordered to install the safety gear, failed to do so, and was injured in the unprotected mechanism. ${ }^{407}$

The court ruled the Primary Duty Rule did not apply to the case. ${ }^{408}$ The court noted that the plaintiff in Walker only sued for Jones Act negligence, so, strictly speaking, the Primary Duty Rule from Walker did not bar seaworthiness claims. ${ }^{409}$ The court found Reinhart's extension of the Primary Duty Rule to an unseaworthiness action unpersuasive and drew a distinction

in order to lower the oil level, otherwise, additional water would cause the oil to rise over the deck again. He then proceeded to install the pump in the engine room, where he fell and suffered his injuries.

Furthermore, had his employer not given him directions, this might be a different case. Joia proceeded only under the general directions of his employer, where in Peymann, the plaintiff proceeded under his own directions. Indeed, under these circumstances, it would have seemed futile for Joia to have first attempted to clean the deck and then to pump the water, and foolish for his employer to have so directed. We cannot say that under Peymann, as a matter of law, Joia breached his duty to maintain a clean engine room. Joia was directed to clean this mess, understood his responsibility to maintain the engine room, and proceeded to remedy the problem in a manner he saw fit.

Id. at 911 .

406. Id. at 911 .

407.

Five or six months prior to Plaintiff's accident, a marine surveying firm had recommended to the ship's owner, who is also its captain, that a protective guard be installed around this alternator and its moving belt or belts. The captain then instructed Plaintiff to install such a guard, but Plaintiff failed to do so. Plaintiff was injured when his pant leg was caught in some part of the alternator, forcing his leg into the hot machinery.

Snow v. Boat Dianne Lynn, Inc., 664 F. Supp. 30, 31 (D. Me. 1987).

408.

In the present case, Defendant undertook the voyage while the ship was in an unseaworthy condition. Although Defendant may have relied upon Plaintiff to remedy the condition during the voyage, it required Plaintiff to do so while the ship was operational and thus exposed Plaintiff to the risk of injury. The Court finds that the existence of the unseaworthy condition and its causal relationship to Plaintiff's injuries are sufficient to impose liability upon Defendant under the doctrine of seaworthiness. The remaining issues of fact pertain to Plaintiff's comparative fault, which may significantly diminish Plaintiff's recovery. These issues are, however, properly reserved for the fact-finder at trial.

Id. at 34 .

409. Id. at 32-33. 
between applying the Rule to unseaworthy conditions that arise before or after the voyage. ${ }^{410}$ The court said other judicial decisions held the Primary Duty Rule does not apply to unseaworthy conditions existing before the voyage, where, presumably, the owner knew and could have repaired the condition using shore side personnel. ${ }^{411}$ In such a case, a seafarer who violates his primary duty to remedy an unseaworthy condition that existed prior to the voyage can recover since the Rule does not apply. But the same seafarer who violates his primary duty to repair an unseaworthy condition that forms after the voyage commences cannot recover.

The court's analysis in Snow is questionable. For one, there is no disputing the condition at issue in Walker, a broken cabinet latch, was an unseaworthy condition, and the court made its holding in consideration of that fact. Moreover, unseaworthiness is not a fault-based cause of action: an owner is strictly liable for any equipment not reasonably fit for its intended use, regardless of actual or constructive notice. An owner cannot delegate this duty, but an owner is not required to provide an accident-free ship either.

The owner must be able to rely on competent employees, whether shoreside or at sea, to perform their duty to maintain and fix equipment in a safe manner. To hold otherwise creates arbitrary distinctions among employees performing identical duties, and is contrary to both Reinhart and Walker. Consequently, it may be more accurate to characterize the Snow court as holding the owner delayed the repairs until it was unsafe to make them, so plaintiff did not violate his primary duty and cause his injury.

Although the Snow court hinted that plaintiff had not violated his duty to install the protective gear because it was unsafe to do so at sea, there were no facts listed that support that position. Indeed, there is no mention of any reason the plaintiff violated his duty. Therefore, the court could have enforced the Rule to the case if plaintiff violated his primary duty to install the safety device, he could have safely performed the duty, and his failure to perform his duty caused his accident.

In McSpirit, a district court in the Second Circuit expressed doubt that the Rule continued in that circuit; the court held that the Rule, if it were good law, did not apply to the facts of the case. ${ }^{412}$ There, the jury found plaintiff was not negligent and the vessel was unseaworthy. ${ }^{413}$ The defendant moved for a directed verdict and judgment notwithstanding the verdict, which the court

410. Id. at 33 .

411. $I d$.

412. McSpirit v. Great Lakes Int'l, 882 F. Supp. 1430, 1431-32 (S.D.N.Y. 1995).

413. $I d$. 
denied. ${ }^{414}$ In its analysis, the court intermingled the Rule with a negligence analysis although the two are distinct. ${ }^{415}$ As said in Walker, momentary neglect of duty is not a basis to bar a claim under the Primary Duty Rule. ${ }^{416}$

In McSpirit, a tug captain fell from a vessel ladder because the ladder lacked non-skid paint. ${ }^{417} \mathrm{He}$ did not know of the unseaworthy condition, though defendant, GLI, had known about the condition for a long period. ${ }^{418}$ Certainly, it could have been argued the captain had a duty to inspect the ship, which he violated resulting in his injury, so the Rule precluded his recovery. However, the court apparently concluded he could not have safely performed his duties since there was a hidden danger he did not know of, but his employer did. ${ }^{419}$ Therefore, the captain did not violate his primary duty. ${ }^{420}$

In Ferreira, the Ninth Circuit in 1998 affirmed a district court's dismissal of an indemnity claim by a defendant shipowner against its employee that negligently injured a co-employee. ${ }^{421}$ The owner asserted the tortfeasor's violation of his primary duty causing an injury to another crewmember should offset the owner's liability via indemnity. ${ }^{422}$ The court rejected the argument and restated that mere neglect by the plaintiff does not comport with application of the Primary Duty Rule. ${ }^{423}$ In order for a plaintiff to be barred from recovery under the Rule, he must violate a positive duty for which he had primary responsibility. ${ }^{424}$ Again, however, the Rule was not applicable to the

In this case, however, the condition found by the jury to have been the result of negligence existed for a substantial period before the voyage on which Mr. McSpirit was injured. (McSpirit Tr. at 93:14-16). It was undisputed that other high ranking employees of GLI knew about the nonskid paint issue. ... In this case, the ladder was unseaworthy prior to the voyage on which Mr. McSpirit was injured. Defendant therefore had the opportunity to maintain the ladder prior to the accident, whereas it would not have had such an opportunity if the ladder had become unseaworthy during the voyage. Since GLI had this opportunity, it could not avoid its non-delegable responsibility under the doctrine of unseaworthiness by claiming that maintenance was the captain's responsibility under Walker.

McSpirit, 882 F. Supp. at 1432-33. But see Reinhart v. United States, 457 F.2d 151 (9th Cir. 1972).

419. McSpirit, 882 F. Supp. at 1431-33.

420. Id.

421. California Home Brands, Inc. v. Ferreira, 871 F.2d 830, 838 (9th Cir. 1988).

422. Id. at 831 .

423. Id. at $835-36$.

424.

However, mere negligence alone would not be sufficient for finding such a breach. In order for the primary duty rule to apply, the employee must have failed to perform a specific, positive duty for 
facts of the case, since the Rule is a defense to a seafarer's action, not a source of a third-party claim. ${ }^{425}$

In White, a state appellate court in California held the Primary Duty Rule did not apply to unlicensed crew. ${ }^{426}$ However, as with other cases in which courts limited the Rule, the White court could have restrained its opinion to the facts of the case, to which the Rule did not apply. ${ }^{427}$ In that case, a chief mate ordered a boatswain (a high-ranking unlicensed seafarer) to secure the anchor, but the latter was unfamiliar with the "devil's claw" device used for that purpose. ${ }^{428}$ During the operation, the boatswain and the two A/B assistants (also unlicensed seafarers) jammed the claw to the anchor, so they lashed a line around the equipment and used a sledgehammer to free them. ${ }^{429}$ A piece of the equipment fell and hit the boatswain's knee. ${ }^{430}$

One of the boatswain's duties was to secure the anchor. However, the chief mate did not properly instruct, or supervise the boatswain, who was unfamiliar with the equipment. ${ }^{431}$ Therefore, it was the mate's violation of his duty to supervise and instruct the crew, not the boatswain's duty to secure the anchor, that caused the incident, so the Rule should not apply for that reason. ${ }^{432}$ There is no substantiated reason to limit application of the Rule to ship's officers alone.

In Krall, the District Court in Louisiana found a plaintiff was solely at fault for a slip and fall in grease so he could not recover. ${ }^{433}$ Plaintiff, an AS/utility worker (not an officer), wore sneakers after being instructed to wear work boots and his footwear caused his misstep. ${ }^{434}$ The Court cited Walker in

which he had primary responsibility. See Hudson Waterways Corp. v. Schneider, 365 F.2d 1012 (9th Cir. 1966). To find otherwise, and equate breach of a primary duty with ordinary negligence, would in effect resurrect contributory negligence as an absolute defense to a shipowner's liability. Id. at 836 (emphasis in original).

425.

Even assuming that Ferreira's alleged negligence amounted to breach of a primary duty, Reinhart has no application in this case, for the primary duty rule works only to bar a plaintiff's suit for damages when his injury resulted from his own breach; it does not create any rights against third parties.

Id. at 836 .

426. White v. Maritime Overseas Corp., 1989 A.M.C. 2070, 2071-73 (Cal. App. 1st Dist. 1989).

427. $I d$.

428. $I d$.

429. $I d$.

430. $I d$.

431. White, 1989 A.M.C. at 2071-73.

432. $I d$.

433. Krall v. United States, 1990 U.S. Dist. Lexis 15998 (E.D. La. 1990).

434. "In conclusion, the Court finds that plaintiff willfully violated the footwear policy [of his 
support of its holding that plaintiff was solely at fault and could not recover. This is a Fifth Circuit case that upheld and enforced the limited version of the Rule. $^{435}$

Plaintiff in Kelley was a mate on towboat injured along with a deckhand. ${ }^{436}$ The men were injured when they pulled on a cable and the keeper slipped causing them both to fall backwards onto the deck. ${ }^{437}$ As the mate on the tugboat, plaintiff was in charge of the deck, and was the deckhand's supervisor. ${ }^{438}$

The mate assumed the deckhand was watching the keeper. ${ }^{439}$ The jury assigned the deckhand, and thus the employer, seventy-five percent fault and found plaintiff twenty-five percent at fault for his failure to supervise the deckhand. The court noted that the keeper slipped only four percent of the times it was used, or about once per month. ${ }^{440}$ The court cited Walker but did not apply the Rule to the facts.

The Seventh Circuit, acknowledging the jury's finding that both the plaintiff and deckhand shared concurrent fault for the incident, decided the case under comparative fault principles. ${ }^{441}$ In its analysis, the Kelly court did not mention whether the accident could have been avoided if plaintiff had performed his primary duty at the time of the incident. ${ }^{442}$ Indeed, the court did not identify the primary duty at issue: whether plaintiff's primary duty was to supervise the deckhand, or safely to loosen the cable while adjusting the keeper. It is possible the court concluded the plaintiff did perform his

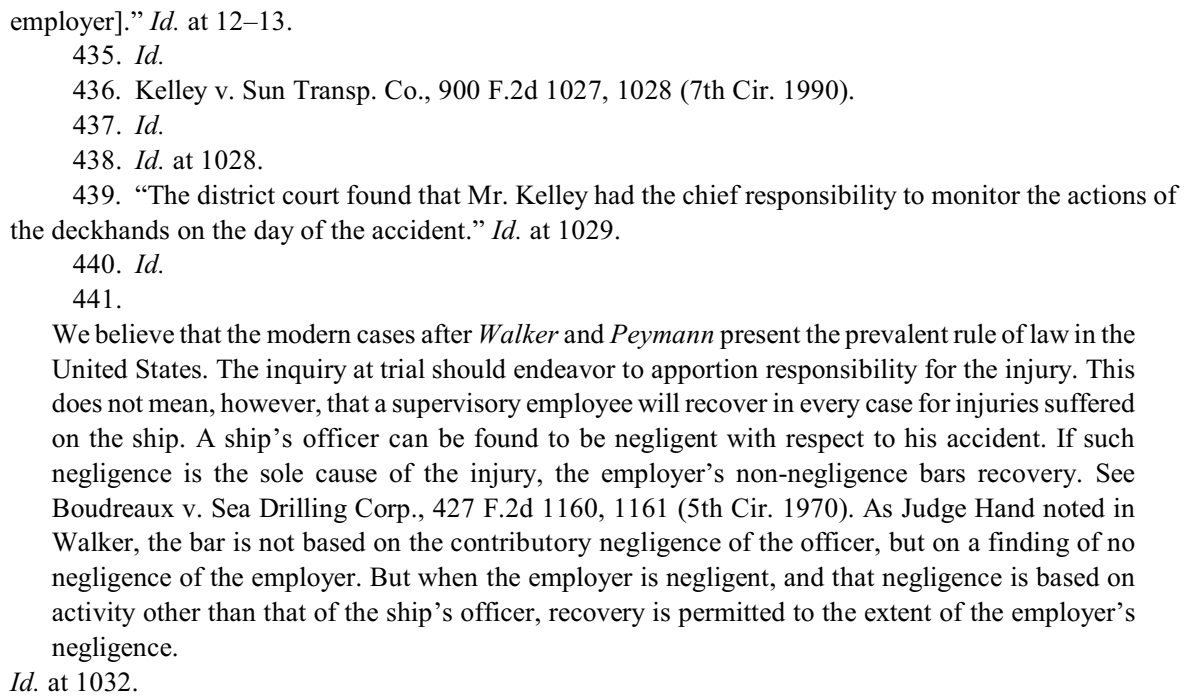


supervisory duty since the keeper problem was such a remote likelihood that the mate's duty was discharged by entrusting the experienced deckhand to watch the keeper. In any event, as with other cases creating the limitations to the Primary Duty Rule, it appears the court in Kelly did not apply the Rule to the facts, or the facts did not warrant application of the Rule.

In 1990, the Ninth Circuit in Bernard held the Primary Duty Rule did not apply to a suit by a chief cook. ${ }^{443}$ The court recognized the Rule and restated it, citing Walker, Reinhart, Ferreira, and Dixon. ${ }^{444}$ In its restatement, the Bernard court emphasized the Rule bars a seafarer from recovery when he "knowingly" violates a conscientiously-assumed duty. ${ }^{445}$

The court cited Walker and made this ruling in the context of a case where the seafarer at issue had arguably violated his duty by neglect, or a momentary lapse. ${ }^{446}$ Therefore, he did not knowingly violate his duty and his suit went forward. The court also distinguished the duty to be performed from the duties pertaining to safety in Walker and Reinhart. ${ }^{47}$

The Bernard court's characterization of Walker's requirement that the Rule applies to a violation of a conscientiously assumed duty is largely correct. Walker recognized a momentary lapse would not preclude recovery under the Rule; rather, one must violate a duty in a manner that would, in

443. Bernard v. Maersk Lines, Ltd., 22 F.3d 903 (9th Cir. 1994).

444. Id. at 907.

445.

From these cases, three limiting principles can be discerned. First, the "primary duty" rule will not bar a claim of injury arising from the breach of a duty that the plaintiff did not consciously assume as a term of his employment. Second, the rule does not apply where a seaman is injured by a dangerous condition that he did not create and, in the proper exercise of his employment duties, could not have controlled or eliminated. Third, the rule applies only to a knowing violation of a duty consciously assumed as a term of employment. It does not apply to a momentary lapse of care by an otherwise careful seaman. Each limitation has relevance when we consider whether Bernard has demonstrated that there are friable issues of fact. $I d$.

446. "The theory [behind the rule] apparently is that a momentary inattention to one's own safety... should not be treated as so serious a fault as the breach of a duty assumed by the employee for the protection of others, although incidentally it is for his own benefit too." Id. at 906 (citing Walker v. Lykes Bros., 193 F.2d 772, 773 (2d Cir. 1952)).

447.

Finally, this is not necessarily a case like Walker or Reinhart in which the plaintiff's claim was barred because he had a duty to maintain safe conditions on a ship, or in a certain area of a ship, knew of an unsafe condition, failed to remedy it, and was eventually injured by it. Benard, 22 F.3d at 908. 
effect, entitle the employer to offset the employee's claim. ${ }^{48}$ Or, as said in Walker, the violation must be "serious."

As with every Primary Duty case, the characterization of the facts in Bernard was pivotal in determining the application of the Rule. In that case, a box of frozen steak fell onto a chief cook as he loaded boxes of stores in a freezer. ${ }^{450} \mathrm{He}$ had been rapidly loading boxes of lobsters and a crewmember suddenly handed the cook a much heavier box of steaks. ${ }^{451}$ Not having time to consider an alternate, he "mechanistically" heaved the heavy box onto the lighter boxes on the shelves, crushing the lighter boxes and causing the heavy box to fall back onto him. ${ }^{452}$

At the time of the incident, the chief steward was in charge of the loading operation, and plaintiff "Bernard was in charge of loading stores in the meat locker" where the incident occurred. ${ }^{453}$ Because the ship was under the Military Sealift Command, military personnel were on board and they took part in a "human conveyer belt" 454 to load the boxes in the freezer. The soldiers rapidly transferred the stores down the line as part of a game to determine how quickly it could be done. The soldiers ignored plaintiff's request to slow down. ${ }^{455}$

It does not appear that plaintiff in the Bernard case violated his primary duty. He loaded the boxes as permitted under the circumstances, and his momentary lapse was not so serious as to qualify as a violation of duty. Of course, it could be argued he did violate his duty to load the meat box safely, and this violation caused his injuries. However, the issue of whether the

448.

[This] result turns really not upon any question of "proximate cause," "assumption of risk" or "contributory negligence," but rather upon the employer's independent right to recover against the employee for the non-performance of a duty resulting in damage to the employer, which in effect off-sets the employee's right to recover against the employer for failure to provide a safe place to work.

Id. at 905 (citing Dixon v. United States, 219 F.2d 10, 16-17 (2d Cir. 1955)). 449.

The theory apparently is that a momentary inattention to one's own safety - the kind of thing of which we are all guilty every day - should not be treated as so serious a fault as the breach of a duty assumed by the employee for the protection of others, although incidentally it is for his own benefit too.

Walker, 193 F.2d at 774.

450. Bernard, 22 F.3d at 904-05.

451. $I d$.

452. $I d$.

453. Id. at 904.

454. $I d$.

455. Id. 
seafarer violated his duty is a question of fact, which the court adequately addressed.

In Fountain, a second captain sued a shipowner after suffering injuries in a fight with the engineer. ${ }^{456}$ The court, at the conclusion of plaintiff's case, found for defendant as a matter of law under the Primary Duty Rule. ${ }^{457}$ plaintiff, an officer, violated the captain's order not to use racial slurs in the engineer's presence. ${ }^{458}$ The plaintiff contravened the order and used the slur, caused the fight, and the Rule barred the suit. ${ }^{459}$ The court also held the shipowner did not negligently cause, or allow, the fight to occur. ${ }^{460}$

In Sparklin, the court cited the Primary Duty Rule, but found it did not bar plaintiff's suit. ${ }^{461}$ There, a railroad employee allegedly violated a company safety rule when he worked on a rail switch without salting the area first. ${ }^{462} \mathrm{He}$ fell on the ice at the switch and sued for personal injuries. ${ }^{463}$ The jury found for plaintiff and awarded him damages. ${ }^{464}$ The employer moved for judgment notwithstanding the verdict and the court denied the motion. ${ }^{465}$

The court said there was evidence defendant had not salted in the days prior to the incident despite having time to do so and knowing employees would be working at the area. ${ }^{466}$ As for the Primary Duty argument, the court denied defendant's motion because the court did not find evidence plaintiff had an "independent" duty to salt the area in the circumstances. Additionally, the evidence indicated there was no salt for plaintiff to use, and the employer was negligent in failing to salt the area before plaintiff began working. ${ }^{467}$

456. Fountain v. John E. Graham \& Sons, 833 F. Supp. 873 (S.D. Ala. 1993), aff'd, 16 F.3d 1232 (11th Cir. 1994) (without opinion).

457. Id. at $875-76$.

458. Id.

459 .

Moreover, misconduct by a ship's officer, such as Fountain, entirely relieves the shipowner of liability under the "Walker doctrine." Walker v. Lykes Bros. Steamship Co., 193 F.2d 772, 774-75

(2d Cir. 1952). See Villers Seafood Co. v. Vest, 813 F.2d 339, 342 (11 th Cir. 1987) (declining to extend Walker to prevent recovery by officer where officer was merely negligent). Id. at 880 .

460. Id. at 878 .

461. Sparklin v. Consolidated Rail Corp., 1995 U.S. Dist. Lexis 10857 (E.D. Pa. 1995).

462. Id. at $1-2$.

463. $I d$.

464. $I d$.

465. $I d$.

466. Sparklin v. Consolidated Rail Corp., 1995 U.S. Dist. Lexis 10857, at 4 (E.D. Pa. 1995).

467. The court noted:

Conrail grounds its argument in the "primary duty rule," which directs that no recovery may be had for injuries that occur due to an employee's failure to perform an independent duty arising out of the employment relationship. See Reinhart v. United States, 457 F.2d 151 (3d Cir. 1957). Conrail 
Plaintiff did not have a duty that he violated so the Rule did not warrant dismissal of his suit.

A district court in the Second Circuit cited the Primary Duty Rule in 1995. In Lombas, the captain of defendant's tug tripped, fell and was injured while walking backwards on a pier. ${ }^{468}$ At the time he fell while walking backwards, he and two other tug captains were pulling the same wire cable. ${ }^{469}$ The two other captains accomplished the task while walking forwards and neither fell. ${ }^{470}$

The task was a "joint job" among three co-employees of the same supervisory rank. ${ }^{471}$ As they walked, Lombas had not been looking where he was going and tripped over a warped board that was part of the pier. ${ }^{472}$ No one instructed him to walk backwards. ${ }^{473}$ There was testimony that Lombas chose to pull the cable manually and could have instead elected to use a mechanical cherry picker to do the job. ${ }^{474}$

The court questioned whether the Primary Duty Rule was good law in the Second Circuit ${ }^{475}$ and said the Rule did not bar the suit, largely without explanation. Somewhat surprisingly, the court then ruled for defendant, stating Lombas was solely at fault and had not demonstrated any neglect by his employer. ${ }^{476}$

argues that under Safety Rule 3033, it was Sparklin's "primary duty" to salt the area in which he was working, and that the evidence established that his failure to do so "caused his injuries." However, Conrail does not address how a safety rule creates an independent duty on Sparklin's part. Thus, this argument again can at most be construed as a reiteration of the contention that because Sparklin did not spread salt before he began working, he is barred from recovery. I have rejected this contention several times above, and I will not repeat my analysis here. This argument provides no cause for a new trial.

Id. at 22-23.

468. Lombas v. Moran Towing \& Transp. Co., 899 F. Supp. 1089, 1091-94 (S.D.N.Y. 1995).

469. $I d$.

470. Id.

471. Id.

472. Id.

473. Id.

474. Lombas, 899 F. Supp. at 1091-94.

475. "Although it is not necessary to apply the Walker doctrine in this case, the court notes that the doctrine is of questionable continued viability in this Circuit." Id. at 1096-97 (citing McSpirit v. Great Lakes Int'1, 882 F. Supp. 1430, 32 S.D.N.Y. 1995).

476. As for the Rule, the court held:

The facts of this case are very different from the specific employment obligations that were imposed on the master in the Walker case. It would not make sense on the facts or the law to apply the Walker doctrine in this case, and the Court has not relied upon it in finding that the plaintiff is not entitled to recover because he has failed to prove by a preponderance of the evidence that the defendant was negligent at all. Moreover, the evidence establishes that the plaintiff's injuries were 
The Lombas court correctly noted the Rule did not apply to the facts of the case. For one, Lombas's primary duty with regard to the cable, and his ship, was unclear. ${ }^{477}$ It appeared the three men of equal rank could not decide who among them would lead the job or the manner in which to accomplish the task. Moreover, there is a question whether Lombas could have performed his duty safely, since the dock where he worked had uneven boards that were a tripping hazard.

In Moore, a supervisor told a ship's cook to clean the stove and make it "like new." stove. ${ }^{479}$ She developed tendonitis and filed a suit. ${ }^{480}$ She won her Jones Act claim for negligence against her employer, with a 35\% reduction for comparative fault. ${ }^{481}$ The court found the Primary Duty Rule did not govern the facts of the case. ${ }^{482}$ For one, the court held the Rule does not apply to an unlicensed crewmember such as the cook. ${ }^{483}$ In addition, the court specifically found it was impossible for the plaintiff to perform the duty she had been assigned. ${ }^{484}$ Moreover, the employer did not provide her adequate training for the task. ${ }^{485}$

caused solely by his own negligence. Id. at 1097.

477. "Even if the doctrine remains viable, however, it is questionable whether it could bar recovery in this case. The facts of who the JUDY's master was on April 8, 1988 are very much in dispute." Id. at 1097.

478. Moore v. The Sally J., 27 F. Supp. 2d 1255 (W.D. Wash. 1998).

479. Id. at $1257-58$.

480. $I d$.

481. $I d$.

482. The court said:

Moore's recovery is not barred under the primary duty doctrine. Generally, this doctrine is applied only to vessel officers and not to unlicensed seamen. Villers Seafood Co., Inc. v. Vest, 813 F.2d 339, 342, 1987 AMC 1850 (11 th Cir. 1987); White v. Maritime Overseas Corp., 1989 AMC 2070 (Cal. App. 1989); 1 T. Schoenbaum, Admiralty and Maritime Law §6-24 at 330 (2d ed. 1994). In order for this doctrine to apply: (1) the seaman must have consciously assumed a duty as a term of employment; (2) the dangerous condition that injured the seaman must have been created by the seaman or could have been controlled or eliminated solely by the seaman in the proper exercise of his or her employment duties; and (3) the seaman must have knowingly violated a duty consciously assumed as a condition of employment. Bernard v. Maersk Lines, Ltd., 22 F.3d 903, 906, 1994 AMC 1663 (9th Cir. 1994). None of these elements apply to Ms. Moore's claim.

7. Ms. Moore was contributorily negligent to the extent of $35 \%$ fault. Any recovery of damages should be adjusted accordingly.

Id. at $1262-63$.

483. Id.

484. "Moore was required to clean the vessel stove 'like new' when there was inadequate equipment on board the vessel to accomplish this task." Moore, 27 F. Supp. at 1261.

485. Id. at 1262. 
The court correctly concluded the Primary Duty Rule did not bar plaintiff's suit in Moore. There was a substantial question whether the duty at issue was one she conscientiously undertook as part of her employment since the employer provided her no training for the job and she could not perform the job. Also, the court found she could not safely perform the task in the circumstances that were present. Accordingly, the court refused to extend the Rule to the facts at issue. However, the court's statement that the Rule only applies to officers is against the precedent cited herein.

In 1998, the First Circuit in Wilson held the Primary Duty Rule could bar a suit by a chief mate. ${ }^{486}$ In that case, the chief mate volunteered to go into cargo hold on a tanker and repair valves that had been broken for a long period of time, and the owner had not fixed them. ${ }^{487}$ The crew flooded the hold with seawater to a sufficient height so the mate could repair the valves while on a raft in the hold ${ }^{488}$ However, while the repair was underway, the captain made a course change, which may have caused a large wave to form in the hold. ${ }^{489}$ The mate claimed the raft on which he was riding surged upward with the unexpected wave inside the hold. The wave caused him to hit a beam at the top of the tank. ${ }^{490}$ As a result, he fractured his spine. ${ }^{491}$ The jury found the vessel was unseaworthy and the unseaworthiness proximately caused the injuries. ${ }^{492}$

The appellate court noted Wilson had volunteered to repair the valves while the vessel sailed. ${ }^{493}$ Moreover, he was not wearing a hardhat or life vest while performing the repairs. ${ }^{494} \mathrm{He}$ had ordered the water level to be lowered before entering the tank, and the crew lowered the level as he ordered. ${ }^{495} \mathrm{He}$ had the safer alternative of performing the repairs while the vessel was docked, and knew the operation at sea was dangerous. ${ }^{496}$

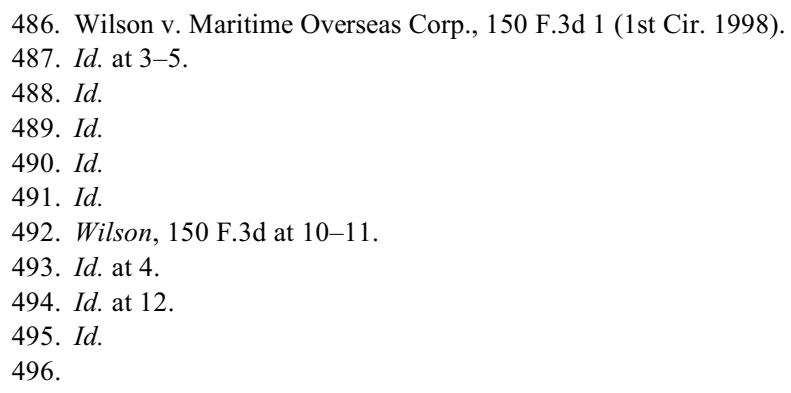

Moreover, here was evidence that: Wilson knew that the repairs were dangerous from his adjustment of the water level prior to boarding the raft, and from his admission that he had never performed this type of repair when the ship was outside of a harbor. A jury could also believe that the wave in the tank was not caused by the vessel's course change, which would undermine Wilson's claim that his 
The jury awarded plaintiff $\$ 2,000,000$ and the defendant appealed based on improper instructions for comparative fault and the Primary Duty Rule. ${ }^{497}$ The court reversed and remanded the case for a new trial, with appropriate jury charges depending on the evidence adduced at trial. ${ }^{498}$

In its opinion, the court in Wilson, like a few others, said the Rule only bars a seafarer's claim when his violation of duty ${ }^{499}$ is the sole cause of his injury ${ }^{500}$ The court also said a charge of comparative negligence would be given if the evidence showed Wilson foreseeably placed himself in a dangerous situation. ${ }^{501}$

injuries were causally related to the defendants' negligence.

Id. at 12 .

497. $I d$. at 3 .

498.

Similarly, an instruction on the primary duty rule must be given if the evidence establishes a genuine controversy as to whether Wilson owed a duty to the defendants, whether he breached the duty, and whether that breach was the sole proximate cause of his injury.

Wilson, 150 F.3d at 11 .

499.

This evidence, together with testimony indicating that Wilson's duties as chief mate included responsibility for the safety and maintenance of the ship, in general, and of the line patching operation, in particular, also suffices to permit a jury to conclude that the only proximate cause of Wilson's injuries was his own failure to perform his duties as chief mate to maintain a safe working environment.

Id. at 12 .

500. The court restated the Rule:

The primary duty rule provides that a ship's officer may not recover against his employer for negligence or unseaworthiness when there is no other cause of the officer's injuries other than the officer's breach of his consciously assumed duty to maintain safe conditions aboard the vessel. See Walker v. Lykes Bros. S.S. Co., 193 F.2d 772, 773 (2d Cir. 1952). In Boat Dagny, Inc. v. Todd, 224 F.2d 208, 210-11 (1st Cir. 1955), this circuit explained that the primary duty rule does not bar recovery where the plaintiff breached his duty but the ship's owner was also independently at fault. 8 "Our decision merely followed the self-evident proposition that not every breach of duty will assign a seaman full responsibility for his injury." Peymann v. Perini Corp., 507 F.2d 1318, 1323 (1st Cir. 1974). The primary duty rule bars recovery only if there was no cause of the officer's injuries other than the breach of duty. "As Judge Hand noted in Walker, the bar is not based on the contributory negligence of the officer, but on a finding of no negligence of the employer." Kelley v. Sun Transp. Co., 900 F.2d 1027, 1031 (7th Cir. 1990).

Id. at 11 .

501. The court stated:

An instruction on comparative negligence must therefore be given if the evidence establishes a genuine controversy as to whether Wilson himself in foreseeable danger even though safer alternatives were available, and whether his choice was the proximate cause of his injuries. Similarly, an instruction on the primary duty rule must be given if the evidence establishes a genuine controversy as to whether Wilson owed a duty to the defendants, whether he breached the duty, and whether that breach was the sole proximate cause of his injury. See Peymann, 507 F.2d at 1323 . We find that the evidence in this case was sufficient to allow a reasonable jury to find 
Wilson again raises a situation when it is clear the seafarer had a primary duty and tried to complete it, but was unsuccessful. In Wilson, plaintiff failed in his duty because he chose the incorrect method to perform his duty, or perhaps, because the captain violated his duty to navigate during repairs and/or to protect the safety of his crew. On remand, if both the captain and chief mate concurrently caused the incident through neglect, the Rule should not bar plaintiff's case and comparative fault should govern. However, if the mate violated his duty to make the repairs and that violation caused his injury, his case should fail under the Rule.

In 2002, the Ninth Circuit in Kinnear applied the Rule to bar a claim by the estate of a deceased captain. ${ }^{502}$ There, all hands were lost when a crabbing vessel sank off Alaska. ${ }^{503}$ The parties stipulated prior to trial the vessel capsized due to instability caused by excessive ice buildup. ${ }^{504}$ In turn, the district court found the captain caused the ice formation by proceeding too rapidly so icy spray covered the deck and weighed the boat down. ${ }^{505}$ The vessel was also unseaworthy as evidenced by a bilge alarm that sounded prior to the casualty, indicating there was excess water in a stern compartment. ${ }^{506}$ Evidence showed the compartment could not be drained because the vessel had too many crab pots on deck. ${ }^{507}$ The spray filling this stern area also weighed the boat down. ${ }^{508}$ The captain controlled the number of pots on board. ${ }^{509}$

The court found the captain's violation of his primary duty to operate the vessel safely caused his death. ${ }^{510}$ In icy conditions the captain went too fast

either that Wilson was contributorily negligent or that his injuries were caused exclusively by his own failure to perform his primary duties.

Wilson, 150 F.3d at 11 .

502. Northern Queen Inc. v. Kinnear, 298 F.3d 1090, 1095-96 (9th Cir. 2002).

503. Id. at 1092-94.

504. $I d$.

505. $I d$.

506. $I d$.

507. $I d$.

508. Kinnear, 298 F.3d at 1092-94.

509. Id.

510. The court held:

Under the primary duty rule, "a seaman-employee may not recover from his employer for injuries caused by his own failure to perform a duty imposed on him by his employment." California Home Brands, Inc. v. Ferreira, 871 F.2d 830, 836-37 (9th Cir. 1989); Reinhart v. United States, 457 F.2d 151, 154 (9th Cir. 1972); see also Wilson, 150 F.3d at 11 ("The primary duty rule provides that a ship's officer may not recover against his employer for negligence or unseaworthiness when there is no other cause of the officer's injuries other than the officer's breach of his consciously assumed duty to maintain safe conditions aboard the vessel."). 
and overloaded the vessel, causing it to become top-heavy and sink. After discussing limits to the application of the Rule not required for its holding, ${ }^{511}$ the Ninth Circuit affirmed the district court's judgment for the employer under a restatement of the Primary Duty Rule. ${ }^{512}$ Since the Captain created the unseaworthy condition and violated his duties to control the conditions once they arose, the Rule precluded his claims. ${ }^{513}$ The court reiterated the Rule applies to a knowing violation of duty and not a momentary lapse of care. ${ }^{514}$

However, in Kinnear, the court could have concluded the vessel was unseaworthy for reasons having nothing to do with the captain. For one, it appeared the stern area of the vessel was not reasonably fit for its intended use. The ship's design allowed pots to enter the area so ice would build up and weigh the vessel down. Also, the court could have concluded the vessel itself was unseaworthy because it was not reasonably fit for its intended use as a fishing vessel in icy waters. Accordingly, in either case, the captain did not cause the unseaworthy condition, but failed to remedy or control it as part of his primary duty to operate the vessel safely. Thus, the court's holding was correct, though its reasoning was outside the primary duty requirements. There is no requirement in the Rule that the plaintiff create the unseaworthy condition at issue, or that the condition arose without employer fault. Neither of these factors was present in Walker, where the captain did not break the

Id. at 1095 .

511. The court held:

We have established limitations on the use of the primary duty rule. First, the duty "will not bar a claim of injury arising from the breach of a duty that the plaintiff did not consciously assume as a term of his employment. Second, the rule does not apply where a seaman is injured by a dangerous condition that he did not create and, in the proper exercise of his employment duties, could not have controlled or eliminated. Third, the rule applies only to a knowing violation of a duty consciously assumed as a term of employment." Bernard v. Maersk Lines, Ltd., 22 F.3d 903, 907 (9th Cir. 1994).

Id. at 1095 .

512. The court said:

Accordingly, in order for an employer to relieve itself of liability under the primary duty rule:

(1) the seaman must have consciously assumed a duty as a term of employment; (2) the dangerous condition that injured the seaman must have been created by the seaman or could have been controlled or eliminated solely by the seaman in the proper exercise of his or her employment duties; and (3) the seaman must have knowingly violated a duty consciously assumed as a condition of employment.

Id. at 1096 (quoting Moore v. Sally J., 27 F. Supp. 2d 1255, 1262-63 (W.D. Wash. 1998)).

513. "In sum, the dangerous conditions confronted by the vessel on March 17 until the time it sunk, were created, in part, by Kinnear's decisions, and could have been controlled or eliminated by the proper exercise of his duties as Captain of the vessel." Id. at 1097-98.

514. Id. at 1098 (citing Bernard, 22 F.3d at 907). 
latches on the cabinet that caused his injury, and subordinate coworkers violated his orders to fix the latches, a fault attributable to the employer.

A district court in Texas granted summary judgment in 2004 under the Primary Duty Rule. ${ }^{515}$ In Malefant, a captain sued for Jones Act negligence and unseaworthiness after he slipped on the top stair as he descended from the wheelhouse. ${ }^{516}$ The court granted summary judgment in defendant's favor since plaintiff violated his duty to inspect and maintain the stairway, and his failure to perform his duty caused his fall. ${ }^{517}$ The court held the injury resulted from the "sole" fault of plaintiff. ${ }^{518}$ Consequently, as in Walker, the unseaworthy condition existed prior to plaintiff"s violation of duty. As in Walker, the captain in Malefant violated his duty to remedy an unseaworthy condition he did not create, and for which the shipowner otherwise would have been liable. ${ }^{519}$ The court's reference to a "negligent" violation of duty is not consistent with Walker.

In another Second Circuit case, the Southern District of New York in Modlin applied the Rule ${ }^{520}$ in 2004 to a chief engineer injured while cleaning parts of a machine that lacked safety guards. ${ }^{521} \mathrm{He}$ had been on the vessel for six months and had taken no steps to remedy the unseaworthy lack of safety guards, and he did not notify the owner of the problem. ${ }^{522}$ Again, plaintiff in this case did not create the unseaworthy condition; he failed in his duty to remedy it. He could have done so safely but did not. He had "consciously

515. Malefant v. Beatty Street Properties, Inc., 328 F. Supp. 2d 668, 669 (S.D. Tex. 2004) (affirmed on the merits, remanded for resolution of maintenance and cure claim the district court failed to address in the summary judgment motion).

516. Id. at 669-70.

517. The court concluded:

The evidence presented to the Court conclusively proves that the sole proximate cause of Plaintiff's injury was the lack of non-skid on the top step. In his deposition, Plaintiff admits that it was his job as Captain to identify problems and perform maintenance on the boat. According to Plaintiff himself, the lack of non-skid on the step was an "oversight" on his part. It was this oversight that was the sole proximate cause of Plaintiff's injury. Since Plaintiff's own negligence was the cause of his injury, he cannot recover against Defendants, and there are no genuine issues of material fact. Id. at 671 .

518. Id.

519. $I d$.

520. The court stated the Rule as:

Under the primary duty doctrine, defendant must prove by a preponderance of evidence, that plaintiff: (1) failed to perform a duty which he consciously assumed as a term of his employment; (2) was injured due to the dangerous condition that he controlled and could have protected against; and (3) that his injury was caused by the knowing failure to carry out his responsibilities. Modlin v. McAllister Bros., 2004 WL 1594859, at 4 (S.D.N.Y. July 15, 2004).

521. Id. at $2-3$.

522. $I d$. at 3 . 
assumed" the duty to fix the safety guard, because the task was part of his duty as chief engineer. ${ }^{523}$

The court rejected plaintiff's argument the Rule applied only to a master and not a subordinate. ${ }^{524}$ The court inferred the chief had had "knowingly" violated his duty by not fixing the safety guards, or notifying the owner of the problem, during the four to six months he had worked in the engine room. ${ }^{525}$ This application of the Rule is consistent with Walker.

In Long, a district court in Virginia incorrectly held the Primary Duty Rule was not applicable to a steward/baker because of his subordinate rank. ${ }^{526}$ Moreover, after criticizing the Rule and pointing out its varied "permutations" among the circuits, the court held the Rule did not govern the facts of the case. $^{527}$

523. The court noted:

There was ample evidence for the jury to conclude that plaintiff failed to perform a duty which he consciously assumed as a term of his employment. As chief engineer, plaintiff acknowledged that he was responsible for performing "any necessary maintenance or repairs in the engine room." (quoting Trial Tr. November 28, 2000, p. 66 lines 1-10, 15-22). "This included the responsibility to "inspect the engine room and report any problems or safety hazards," and to, "control or eliminate ... dangerous conditions."

$\ldots$

"Evidence adduced at trial showed, however, that plaintiff had never notified defendant concerning the adequacy of the guard. . . Further evidence showed that as the chief engineer, plaintiff was responsible for creating and maintaining a safe work environment in the engine room. See Trial Tr. p. 66 line 1. This included the responsibility to "inspect the engine room and report any problems or safety hazards," and to, "control or eliminate ... dangerous conditions."

Id. at 2 .

524. The court said:

Plaintiff also argued that the primary duty charge was inappropriate because he was not the master of the vessel, but only assumed the duty of a lower echelon employee. The primary duty doctrine, however, applies generally to a breach of contractual duty by an employee and does not depend upon the rank of the employee. The fact that plaintiff was not the master of the vessel does not preclude the defense as long as plaintiff had specific employment obligations to protect against the injury that had been sustained.

Id. at 3 (emphasis added).

525. "Further testimony adduced at trial indicates that plaintiff's injury had been caused by a knowing failure to carry out his responsibilities to protect against unsafe conditions. Specifically, a plaintiff must know of the dangerous conditions and fail to act and correct them after having a reasonable opportunity to do so." Id. at 5.

526. "While Long was in a supervisory position, like Mason, he was a general seaman rather than captain of the ship. As such, under the Fourth Circuit precedent of Mason, Long's recovery should be reduced under principles of contributory negligence, rather than completely barred under the primary duty rule.” Long v. United States, 339 F. Supp. 2d 729, 734 (E.D. Va. 2004) (citing Mason v. Lynch Bros., 228 F.2d 709 (4th Cir. 1956)).

527.

In the First, and Seventh Circuits, the primary duty rule only applies when there is no other cause for the injury but a breach of an employment duty by the plaintiff. It does not apply when the 
In Long, plaintiff was head of the steward department comprised of him and two others. ${ }^{528}$ Plaintiff claimed the stores freezer was overloaded before he boarded the vessel so the captain ordered him and his department to rearrange the contents. ${ }^{529}$ Plaintiff and his crew rearranged the items on the freezer floor, but he claimed he did not have authority to move the meat from the shelves since the freezer was full and the meat would have to be moved elsewhere on the vessel. ${ }^{530} \mathrm{He}$ later reentered the freezer and a piece of frozen meet fell from a shelf and injured his foot. ${ }^{531}$

The court ruled the Primary Duty Rule did not apply to the facts of the case since there was no evidence plaintiff disregarded his duty, and there was no evidence he could have safely performed his duty. ${ }^{532}$ The court held the case would be covered by comparative principles, and not the Primary Duty Rule. $^{533}$

It seems unlikely plaintiff could not have safely completed his duties in Long. The court's decision does not explain the reason plaintiff could not ask for authority to move the meat from the shelves as part of his duty to clean out the freezer. Perhaps the court concluded there was nowhere else on the vessel where the meat could have been moved, so plaintiff could not have performed his duties safely.

The District Court of Connecticut in 2006 questioned the continued strength of the Primary Duty Rule, and held it did not apply to the facts of the

employer is also at fault in any degree. While stated as a special rule, it does the same analytic work as the test for negligence. Either stated as a special rule or stated as part of the Jones Act negligence test, at the heart of every action under the Jones Act there has to be at least a small amount of negligence on the part of someone other than the injured person. If under the Fourth Circuit's test for Jones Act negligence a plaintiff is successful, the plaintiff also defeats the primary duty rule as articulated by the First and Seventh Circuits. Accordingly, this permutation of the primary duty rule does not affect the result in this case. Id.

528. Id. at $730-32$.

529. Id.

530. $I d$.

531. Id.

532.

Even if the plaintiff assumed the duty of keeping the freezer safe, the plaintiff clearly did not create the dangerous situation; the piece of meat that injured him was stored on the shelf before the plaintiff signed on the ship and he never moved it. It is factually contested whether he could have eliminated the condition. As discussed in Part II.A, it is not clear whether there was any place where he could have moved the meat to eliminate the dangerous condition. Finally, even assuming that there was someplace else where the meat could have been stored, there is no evidence that Long consciously disregarded his duty to make sure the food was secured in the freezer.

Long, 399 F. Supp. 2 d at 735.

533. Id. 
case Borges. ${ }^{534}$ There, a Chief Mate fell while inspecting a ballast tank on a product tanker. ${ }^{535}$ She claimed the vessel was unseaworthy because there was inadequate lighting and the employer failed to provide a reasonably safe workplace. ${ }^{536}$ The defendant moved for summary judgment under the Rule and the Court denied the motion as premature, and not applicable to the facts. ${ }^{537}$

In that case, the court, viewing the facts in the light most favorable to plaintiff, indicated improper lighting caused the accident. The court also said there was no evidence, at the summary judgment stage, that plaintiff's duty to inspect the hold included a duty to procure or replace the lights in the hold. ${ }^{538}$

From the facts listed, it appears plaintiff could not have safely performed her duty to inspect the tank because there was improper lighting. (There is nothing in the opinion about the use of flashlights.) The court's reasoning would have been more consistent with other courts if it had held the plaintiff's duty at the time of the incident was to inspect the tank, and she could not safely discharge that duty so the Rule did not apply.

The Sixth Circuit in Churchwell denied defendant's argument that the Primary Duty Rule should bar a suit by a cook who slipped on grease on the galley floor after she spilled the grease there. ${ }^{539}$ The court said plaintiff, who was not an officer, did not breach a conscientiously-assumed the duty to maintain safe conditions on the vessel. ${ }^{540}$ In its restatement of the Rule, the

534. Borges v. Seabulk Int'1, Inc., 456 F. Supp. 2d 387, 392-93 (D. Conn. 2006).

535. Id. at 389 .

536. Id.

537.

There is a genuine issue of material fact as to whether the plaintiff's consciously assumed duty, as the seaman primarily responsible for safety on the ship, extended to furnishing the vessel with specific equipment that the owner had not supplied despite repeated requests. Moreover, there is sufficient evidence for a reasonable jury to conclude that the plaintiff's injuries were in fact a result of the defendants' breach of their own duty to provide their employees with a safe workplace and/or a seaworthy vessel. Under either scenario, the Primary Duty Rule would be inapplicable. Therefore, the Primary Duty Rule cannot act as a bar to the plaintiff's claims at the summary judgment stage, and its applicability must be submitted to the trier of fact.

Id. at 393.

538. "There is a question whether she, the mate, consciously assumed the duty of equipping the ship, though she requested the lights prior to the incident. There is also a question whether the incident resulted from defendant's failure to provide a reasonably safe place to work." Id.

539. Churchwell v. Bluegrass Marine, Inc., 444 F.3d 898 (6th Cir. 2006).

540. The court held:

The primary duty rule has no place in this case. In order for the primary duty doctrine to apply, the defendant must offer evidence that the Plaintiff "consciously assumed [the] duty to maintain safe conditions aboard the vessel." Wilson, 150 F.3d at 11 . There is absolutely no evidence that Plaintiff consciously assumed any such duty. See Ribitzki, 111 F.3d at 665-66 ("[T] he rule only applies to a knowing violation of a duty consciously assumed as a term of employment."); cf. Malefant $v$. 
court added that the Rule applies when plaintiff's violation of duty is the sole cause of the injury. Additionally, the court indicated that if the plaintiff and employer concurrently cause the injury, the case should be decided under a comparative fault analysis. ${ }^{541}$

In Churchwell, the cook claimed she had been instructed to dispose of grease from the stove by pouring it into a coffee can. ${ }^{542}$ After filling the can with grease, she dropped the can as she gripped its lip between her thumb and fingers. The can spilled onto a mat and she slipped on the greasy mat. ${ }^{543}$ The district court granted summary judgment after granting defendant's unopposed motion in limine to exclude plaintiff's engineering expert. ${ }^{544}$ The expert was to testify that the shipowner should have provided another type of floor mat and another grease disposal system. ${ }^{545}$ Without the expert, the district court granted summary judgment to defendant since plaintiff failed to prove the shipowner deviated from ordinary care. ${ }^{546}$ The appellate reversed, holding in part, that plaintiff did not violate her primary duty. Id. The court did not offer a detailed explanation for this aspect of its holding.

Presumably, the court made its holding with the view that plaintiff did not have a choice regarding the types of grease container or floor mat, which were unsafe, so she did not violate her duty safely to dispose of the grease. The court may also have based its holding on the theory that plaintiff's duty did not include an obligation to use unsafe equipment. In either case, the court recognized the Rule, but held it did not apply to the facts under review.

In a 2007 FELA case, the Supreme Court, in Sorrell, ${ }^{547}$ recognizing a limit in the indulgence extended to seafarers, ${ }^{548}$ held the identical "in whole

Beatty St. Props., Inc., 328 F. Supp. 2d 668 (S.D. Tex. 2004) (holding that the primary duty rule precluded recovery where the plaintiff slipped because of missing non-skid tape, which it was the plaintiff's duty to insure was in place). Therefore, the primary duty rule does not make summary judgment proper in this case.

Id. at $909-10$.

541. "“ $[T]$ he primary duty rule does not bar recovery where the plaintiff breached his duty but the ship's owner was also independently at fault.' $I d$. In such cases, the jury must apply the doctrine of comparative negligence." Id. at 909 (citing Wilson).

542. Id. at $901-03$.

543. $I d$.

544. $I d$.

545. Churchwell, 444 F.3d at 902-04.

546. Id. at 909 .

547. Norfolk S. Ry. Co. v. Sorrell, 549 U.S. 158 (2007).

548. The Court announced:

It does not follow, however, that this remedial purpose requires us to interpret every uncertainty in the Act in favor of employees. See Rodriguez v. United States, 480 U.S. 522, 526, 107 S. Ct. 1391, 94 L. Ed. 2d 533 (1987) (per curiam) ("[I]t frustrates rather than effectuates legislative intent 
or in part" causation standard applies to the analysis of the connection between owner/defendants' fault and the employee's injury, and the link between plaintiff/employee's comparative fault and the injury. ${ }^{549}$

In that case, a FELA trackman injured his neck and back while working for a train company. ${ }^{550} \mathrm{He}$ sued in Missouri state court and the jury awarded him $\$ 1.5$ million. ${ }^{551}$ The jury based its decision on jury charges that differentiated the standard of care owed by the employer to the employee, and the care owed by plaintiff to himself. ${ }^{52}$ The Court rejected plaintiff's arguments regarding the remedial purpose of FELA, and the Court's liberal construction of the statute required a more exacting standard of causation in the comparative fault jury charge. ${ }^{553}$ The Court acknowledged FELA abolished common-law defenses such as assumption of the risk and the fellow-servant rule, and said the common law is entitled to great weight when not expressly rejected by the statute. ${ }^{554}$ Consequently, the same causation standard applies to analysis of the connection between employer's conduct to the injury as does the evaluation of the link between plaintiff's conduct and the injury.

simplistically to assume that whatever furthers the statute's primarily objective must be the law"). FELA's text does not support the proposition that Congress meant to take the unusual step of applying different causation standards in a comparative negligence regime, and the statute's remedial purpose cannot compensate for the lack of a statutory basis.

Id. at 171

549. The court said:

The question presented in this case is a narrow one, and we see no need to do more than answer that question in today's decision. As a review of FELA model instructions indicates . . there are a variety of ways to instruct a jury to apply the same causation standard to railroad negligence and employee contributory negligence. Missouri has the same flexibility as the other States in deciding how to do so, so long as it now joins them in applying a single standard. ...

We conclude that FELA does not abrogate the common-law approach, and that the same standard of causation applies to railroad negligence under Section 1 as to plaintiff contributory negligence under Section 3.

Id. at $171-72$.

550. Id. at 158 .

551. Id.

552. The court listed the facts:

Missouri purports to apply different standards of causation to railroad and employee contributory negligence in its approved jury instructions for FELA liability. The instructions direct a jury to find an employee contributorily negligent if the employee was negligent and his negligence "directly contributed to cause" the injury, (citation omitted) while allowing a finding of railroad negligence if the railroad was negligent and its negligence contributed "in whole or in part" to the injury (citation omitted).

Id. at 161 .

553. Sorrell, 549 U.S. at 171. See also Gautreaux, 107 F.3d at 335.

554. Sorrell, 549 U.S. at 171. 
The Sorrell case is important in the Primary Duty context since Sorrell points out that not all rules must necessarily favor the seafarer, and courts must follow common law not overruled by statute. Since the Primary Duty Rule is a common-law precedent not abolished by statute, under Sorrell, the Rule deserves weight and precedential value.

\section{Circuits}

As noted above, the Fifth Circuit, in particular, has distinguished the Primary Duty Rule, largely relying on the "swept into discard" dicta from Tiller. Fifth Circuit cases such as Dixon, Johnson, Schlichter and Rivers reflect this trend, though that circuit's decision in Atchinson was a basis for the Rule, and cases such as Krall enforce a limited version of the Rule. Other courts, such as the Fourth Circuit in Mason and Long, limit and rarely apply the Rule. The Second Circuit, the source of Walker, inconsistently applies the Rule as seen in Dunbar, Lombas and McSpirit. However, as demonstrated above, the Rule remains good law in all the circuits and the theories underlying the Rule, if applied as originally intended, remain a viable part of maritime personal injury law.

\section{Model Jury Charge}

There are several derivations of the Primary Duty Rule jury charge cited in this article. ${ }^{55}$ The Federal Model Charge requires the injury to be caused solely by plaintiff. It adds that the dangerous condition causing the injury must have been created by plaintiff or, if not, protected against by plaintiff as part of his employment duties. Lastly the federal charge requires plaintiff knowingly failed to carry out his duties, meaning he knew of a dangerous condition and did not act to correct it. ${ }^{556}$

555. See Modlin v. McAllister Brothers, Inc., 2004 A.M.C. 2167 (S.D.N.Y. 2004).

Under the primary duty doctrine, defendant must prove by a preponderance of evidence, that plaintiff: (1) failed to perform a duty which he consciously assumed as a term of his employment; (2) was injured due to the dangerous condition that he controlled and could have protected against; and (3) that his injury was caused by the knowing failure to carry out his responsibilities. (citation omitted). See also Moore v. Sally J, 27 F. Supp. 2d 1255, 1262-63 (W.D. Wash. 1998); N. Queen Inc. v. Kinnear, 298 F. 3d 1090, 1095-96 (9th Cir. 2002).

556. 5-90 Model Federal Jury Instructions-Civil 90.03 (Matthew Bender)

The defendant has introduced evidence that the injury to the plaintiff was caused solely because the plaintiff failed to perform a duty which he or she had consciously assumed as a term of employment. If you find that the defendant has proven by a preponderance of the evidence all three elements of 
The Model Charge attempts to accommodate the major Primary Duty cases, but yields a potentially inconsistent test. For example, the Model Charge requires the injury to be caused solely by a failure to perform a duty, but adds that the dangerous condition at issue may have been created by plaintiff, or otherwise, so long as he knew about it. Courts cited in this article have interpreted similar language to negate the Primary Duty Rule when a dangerous condition is created a by another seafarer, so fault is attributable to the employer. These courts generally found plaintiff's violation of duty was not the "sole" cause of the injury since the condition itself was created by the fault of a co-employee for whom the owner is liable.

However, as demonstrated above, this theory is inconsistent with the holding in Walker which does not hinge on how the condition at issue arose. Moreover, the Model Charge limits the Rule to a duty to protect against the unsafe condition that causes the injury. Again, this condition in the Model Charge invites misapplication. For example, strict application of the Model Charge could have rendered the Rule inapplicable to the captain in Walker because his primary duty arguably was supervisory and not actually to fix the broken latch at issue. Likewise, the Model Charge may incorrectly not have applied to the Chief Mate in Reinhart who failed to use adequate lighting while inspecting a hold. Under the Model Charge, he may not have violated his duty to inspect and maintain the sheathing over the cargo in the hold since these may not have been considered duties to protect against unsafe conditions.

Although primary duties could be connected to safety, there is nothing in the Rule that requires the duty at issue must be one pertaining to safety. If plaintiff violated his duty and was injured as a result, the Rule precludes recovery.

\footnotetext{
this defense as I shall describe them, then you should render a verdict in favor of the defendant. First, the defendant must prove that plaintiff's injury was caused by the plaintiff's failure to perform a duty which he or she had consciously assumed as a term of employment. This means that it was one of the plaintiff's principal duties as a member of the crew to protect against the existence of the unsafe condition which caused the accident.

Second, the defendant must prove that the plaintiff was injured by a dangerous condition that the plaintiff either created or knew existed and, in the proper exercise of his or her employment duties, should have controlled or protected against.

Third, the defendant must prove that the plaintiff's injury was caused by a knowing failure to carry out his or her responsibilities to protect against that unsafe condition. This means that the plaintiff must have known of the dangerous condition and failed to act to correct it after having a reasonable opportunity to do so, and that the accident was not caused simply by a momentary lapse of attention for his or her own safety.
} 
Another source of confusion among the courts, though perhaps not in the Model Charge, is the voluntariness aspect of the duty violated. "Consciouslyassumed duty" does not mean the seafarer volunteered for the specific task at some point shortly before the incident. The term indicates the duty at issue was a positive duty of employment, so plaintiff's violation of the duty is not neglect resulting from a failure to act reasonably under the circumstances. Instead, the violation is a decision not to act when action is required because of job title or responsibility, discussed in more detail, infra. For example, engineers have many duties pertaining to the engine room, deck officers have navigational duties and supervisory duties and deckhands have maintenance and navigational responsibilities. Each title has duties the employee conscientiously assumes by working in that capacity.

Additionally, the seafarer's rank is relevant only in determining his or her duties; rank is not a precondition to application of the Rule.

Accordingly, the Rule applies to a violation that acts to offset the employer's liability. Since the "consciously assumed" language is often misunderstood, it should be discarded. Of course, if the seafarer is negligent, the ordinary Jones Act negligence and comparative negligence rules apply.

\section{Determining a Seafarer's Primary Duty}

When evaluating whether a seafarer has violated his primary duty, a court must necessarily identify the duty at issue. Some courts have labeled certain duties for seafarers in a set of circumstances, such as the master in Hickman who had a duty to sound the general alarm of a tug that later capsized. ${ }^{57}$

Most cases in this article list specific employment duties in certain situations. A party evaluating the Primary Duty Rule may also consult books such as the Merchant Marine Officers' Handbook, ${ }^{558}$ the American Merchant Seaman's Manual, ${ }^{559}$ and discuss the issue with marine experts. The employer's handbook, or SOLAS manual, ${ }^{560}$ could also provide helpful information. In any event, the duty at issue must be clearly articulated.

557. Hickman v. Taylor, 75 F. Supp. 528 (D. Pa. 1947).

558. For example, the Handbook has sections entitled "Deck Officers' Duties and "Duties of the Chief Mate," and lists the Chief Mate's duty to supervise other officers and ensure the Master's orders are executed. Rurpin \& MacEsen, Merchant Marine Officer's Handbook 1-20-1 (1965).

559. For example, the Manual says "Safety is the business of all hands." HaYler, AMERICAN Merchant Seaman's Manual 20-1 (2003).

560. International Convention for the Safety of Life at Sea. 


\section{Primary Duty Rule Restated}

Neither Walker, nor any case leading to it, requires require the seafarer's violation of duty to be the "sole" cause of his injury, meaning the Rule will not apply if the condition arose from fault attributable to the owner. Indeed, in Walker, there was no mention of how the unseaworthy condition arose-whether by employer fault or otherwise. Other cases, such as Wiles and Hylton, explicitly rejected that an owner's fault in creating a dangerous condition relieves a seafarer from his Primary Duty.

Moreover, in evaluating whether the Rule applies, fault is irrelevant, both in terms of how a dangerous condition arose, and the basis for the seafarer's violation of duty. This is true whether the condition arose in whole or in part from the owner's neglect. By definition, most conditions at issue in this article are unseaworthy because each appurtenance was unfit for its intended use. The owner would be liable regardless of how the condition formed, through neglect, freak accident or otherwise. However, once an unseaworthy condition exists, the owner must be able to rely on its trained and competent seafarers to evaluate and address the condition, each according to his duty.

Repairing and maintaining ships necessarily entail duties that involve remedying unseaworthy conditions, however created. Therefore, the language that the violation of duty is the "sole" cause of an incident should be discarded from the Rule. However, the owner is not entitled to send a seafarer into a situation likely to cause an injury and claim the Rule as a shield to liability. The seafarer must be able to accomplish the duty at issue in a safe manner or the Rule should not bar recovery. This can be seen in the engineer in Schneider who had to work on an electrified box, the steward in Long who loaded boxes in unsafe conditions, the Chief Mate in Borges who had to inspect a hold that had improper lighting, and the crewmember in Yehia who had to shovel bulk cargo and spray the hold with a pressurized hose while standing on a steeply-pitched floor covered by grease and oil. ${ }^{561}$

This article suggests the following jury charge for Primary Duty Rule cases:

561. The rule is not different in this circuit:

A seaman may not be denied recovery because he proceeds in an unsafe area of the ship or uses an unsafe appliance in absence of a showing that there was a safe alternative available to him. (citation omitted).

In the case at bar there was not a shred of evidence that Mr. Yehia had a safe alternative available to him. The district court implicitly recognized as much. Yehia, 898 F.2d at 1183. 
1. At the time of the incident, did the plaintiff have an immediate, primary duty to (describe duty) which he assumed as part of his employment and/or job position?

2. Could the plaintiff have performed the immediate, primary duty safely? ${ }^{562}$

3. Did plaintiff knowingly violate his immediate, primary duty?

4. Did the plaintiff's violation of his immediate, primary duty cause his injuries? ${ }^{563}$

If the jury answers each question in affirmative, the Primary Duty Rule precludes the plaintiff from recovering under the Jones Act or for unseaworthiness.

\section{Practical Considerations}

Since the defendant asserting the Primary Duty Rule carries the burdens of proof and persuasion for that claim, ${ }^{564}$ the Rule should be pled in the Answer, subject to Rule $11 .{ }^{565}$ Moreover, Rule $26^{566}$ requires the defendant

562. See Yehia, at 1183.

563. See Reinhart v. United States, 457 F.2d 151, 154 (9th Cir. 1972).

564.

It may be asked, why, if the plaintiff was at fault in failing on so many occasions to make any effective effort to get the catches mended, the judge ought not to have directed a verdict against him. That might have been true, if the burden had not been upon the defendant to prove not only that the plaintiff had been at fault but that his fault had been a cause of his injury, concurrent with the faults of other employees.

Walker v. Lykes Bros. S.S. Co., 193 F.2d 772, 776 (2d Cir. 1951) (emphasis added); see also Wilson v. Maritime Overseas Corporation, 150 F.3d 1(1st Cir. 1998).

565.

By presenting to the court a pleading, written motion, or other paper-whether by signing, filing, submitting, or later advocating it - an attorney or unrepresented party certifies that to the best of the person's knowledge, information, and belief, formed after an inquiry reasonable under the circumstances:

....

(b)(2) the claims, defenses, and other legal contentions are warranted by existing law or by a nonfrivolous argument for extending, modifying, or reversing existing law or for establishing new law....

FED. R. CIV. P. 11(b)(2).

566.

(a) Required Disclosures.

(1) Initial Disclosures.

(A) In General. Except as exempted by Rule 26(a)(1)(B) or as otherwise stipulated or ordered by the court, a party must, without awaiting a discovery request, provide to the other parties:

(i) the name and, if known, the address and telephone number of each individual likely to have discoverable information - along with the subjects of that information - that the disclosing party 
voluntarily and at the inception of the litigation, to produce the documents in support of the defense. In a Primary Duty case, these documents would likely include the seafarer's articles of employment, any safety manual, seafarer training records, seafarer licenses and certifications and standing orders.

It is important, though, not to shoehorn the Primary Duty Rule into a case where it does not belong. Many of the cases in this article that add unwarranted qualifications and conditions to the Rule are cases in which the Rule should not have been argued.

Books such as the seafarer's manuals and handbook cited, supra, can be used as a reference in determining seafarer's primary duty. However, this issue likely will turn upon expert opinion.

\section{CONCLUSION}

Most courts agree the Primary Duty Rule precludes a seafarer's unseaworthiness and Jones Act negligence causes of action when a seafarer's violation of a primary duty causes his or her injury. Most courts that differ focus on the causation aspect of the Rule and require the plaintiff must solely be at fault for the Rule to apply.

However, as demonstrated in this article, the manner in which an unseaworthy condition arose is immaterial; if a seafarer had a duty to remedy the condition, and he could do so safely but violated that duty, he should not recover for a resulting injury.

The Rule is distinct from a determination of fault. Here, the questions are straightforward. A court asks whether the seafarer had a primary duty to perform, if he could have performed it safely, if he knowing violated his duty, and if the injury resulted from the violation of duty. If these are answered in the affirmative, the seafarer should not recover, regardless of how the condition at issue was created, whether by neglect or unforeseen failure.

may use to support its claims or defenses, unless the use would be solely for impeachment; (ii) a copy — or a description by category and location — of all documents, electronically stored information, and tangible things that the disclosing party has in its possession, custody, or control and may use to support its claims or defenses, unless the use would be solely for impeachment; .... FED. R. CIV. P. 26(a)(1)(A)(i)-(ii). 